The University of Maine

\title{
DigitalCommons@UMaine
}

Marine Sciences Faculty Scholarship

School of Marine Sciences

6-15-2001

\section{Seasonal Climatology of Hydrographic Conditions in the Upwelling Region Off Northern Chile}

\author{
J.L. Blanco \\ Andrew Thomas \\ University of Maine - Main, thomas@maine.edu \\ M.E. Carr \\ P. T. Strub
}

Follow this and additional works at: https://digitalcommons.library.umaine.edu/sms_facpub

\section{Repository Citation}

Blanco, J. L.; Thomas, Andrew; Carr, M. E.; and Strub, P. T., "Seasonal Climatology of Hydrographic Conditions in the Upwelling Region Off Northern Chile" (2001). Marine Sciences Faculty Scholarship. 114.

https://digitalcommons.library.umaine.edu/sms_facpub/114 


\title{
Seasonal climatology of hydrographic conditions in the upwelling region off northern Chile
}

\author{
J.L. Blanco, ${ }^{1,2}$ A.C. Thomas, ${ }^{3}$ M.-E. Carr, ${ }^{4}$ and P.T. Strub ${ }^{5}$
}

\begin{abstract}
Over 30 years of hydrographic data from the northern Chile $\left(18^{\circ} \mathrm{S}-24^{\circ} \mathrm{S}\right)$ upwelling region are used to calculate the surface and subsurface seasonal climatology extending $400 \mathrm{~km}$ offshore. The data are interpolated to a grid with sufficient spatial resolution to preserve crossshelf gradients and then presented as means within four seasons: austral winter (JulySeptember), spring (October-December), summer (January-March), and fall (April-June). Climatological monthly wind forcing, surface temperature, and sea level from three coastal stations indicate equatorward (upwelling favorable) winds throughout the year, weakest in the north. Seasonal maximum alongshore wind stress is in late spring and summer (DecemberMarch). Major water masses of the region are identified in climatological $T-S$ plots and their sources and implied circulation discussed. Surface fields and vertical transects of temperature and salinity confirm that upwelling occurs year-round, strongest in summer and weakest in winter, bringing relatively fresh water to the surface nearshore. Surface geostrophic flow nearshore is equatorward throughout the year. During summer, an anticyclonic circulation feature in the north which extends to at least $200 \mathrm{~m}$ depth is evident in geopotential anomaly and in both temperature and geopotential variance fields. Subsurface fields indicate generally poleward flow throughout the year, strongest in an undercurrent near the coast. This undercurrent is strongest in summer and most persistent and organized in the south (south of $21^{\circ} \mathrm{S}$ ). A subsurface oxygen minimum, centered at $\sim 250 \mathrm{~m}$, is strongest at lower latitudes. Low-salinity subsurface water intrudes into the study area near $100 \mathrm{~m}$, predominantly in offshore regions, strongest during summer and fall and in the southernmost portion of the region. The climatological fields are compared to features off Baja within the somewhat analogous California Current and to measurements from higher latitudes within the Chile-Peru Current system.
\end{abstract}

\section{Introduction}

In addition to their intrinsic value in describing oceanic conditions, long-term means, or climatologies, are essential for identification and quantification of interannual or longer timescale variability in the ocean. As an example, the California Cooperative Fisheries Investigation (CalCOFI) time series of physical and biological measurements in the southern part of the California Current has made possible the quantification of variability on a range of timescales. These include the seasonal cycles of currents and water properties [Chelton, 1984; Lynn and Simpson, 1987], interannual variability in currents, water masses, and zooplankton volumes [Chelton et al., 1982] as well as longterm changes in the ecosystem [Roemmich and McGowan, 1995]. Climatologies applicable to regional coastal oceanographic processes require higher spatial resolution than is

\footnotetext{
${ }^{1}$ Instituto de Fomento Pesquero, Valparaíso, Chile.

${ }^{2}$ Now at Department of Ocean, Earth and Atmospheric Sciences, Old Dominion University, Norfolk, Virginia.

${ }^{3}$ School of Marine Sciences, University of Maine, Orono, Maine.

${ }^{4} J e t$ Propulsion Laboratory, California Institute of Technology, Pasadena, California.

${ }^{5}$ College of Oceanic and Atmospheric Sciences, Oregon State University, Corvallis, Oregon.
}

Copyright 2001 by the American Geophysical Union.

Paper number 2000JC000540.

0148-0227/01/2000JC000540\$09.00 usually available from global-scale climatologies, such as that provided by Levitus and Boyer [1994]. All climatologies attempt to maximize the data for each grid point. Because data density is low in most open-ocean regions, large grid box sizes are necessary for global climatologies, making accurate representation of coastal features impossible. Basin-scale [Lozier et al., 1995] and subbasin-scale climatologies of the North Atlantic [Kearns and Rossby 1998] and the Mediterranean [Brasseur et al., 1996] take advantage of higher data density in their regions of interest and are better able to resolve smallerscale features. Resolution of the Mediterranean Oceanographic Data Base is $0.25^{\circ}$ and that of the North Atlantic Current Region is $0.5^{\circ}$. The climatology of the North Atlantic Current region has proven useful in identifying the frontal path of the North Atlantic Current [Kearns and Rossby, 1998], as a comparison to field data [Carr et al., 1997], as an aid in field program design, and as model input [Rowley and Rothstein, 1998].

Here we present the climatological hydrography and circulation of the northern Chile upwelling region between $18^{\circ} \mathrm{S}$ and $24^{\circ} \mathrm{S}$ (Figure 1). This area is embedded within the larger Peru-Chile Current system, which supports one of the most productive fisheries in the global ocean. Combined annual landings of all pelagic fish off Peru and Chile typically range from 12 to 18 million metric tonnes (MMT), out of a total global catch of $\sim 80$ MMT. Approximately 5-6 MMT are caught off Chile, and of this amount about one third (2 MMT of mostly small pelagic fish such as anchovy and sardines) are caught off northern Chile. However, this catch is subject to large 


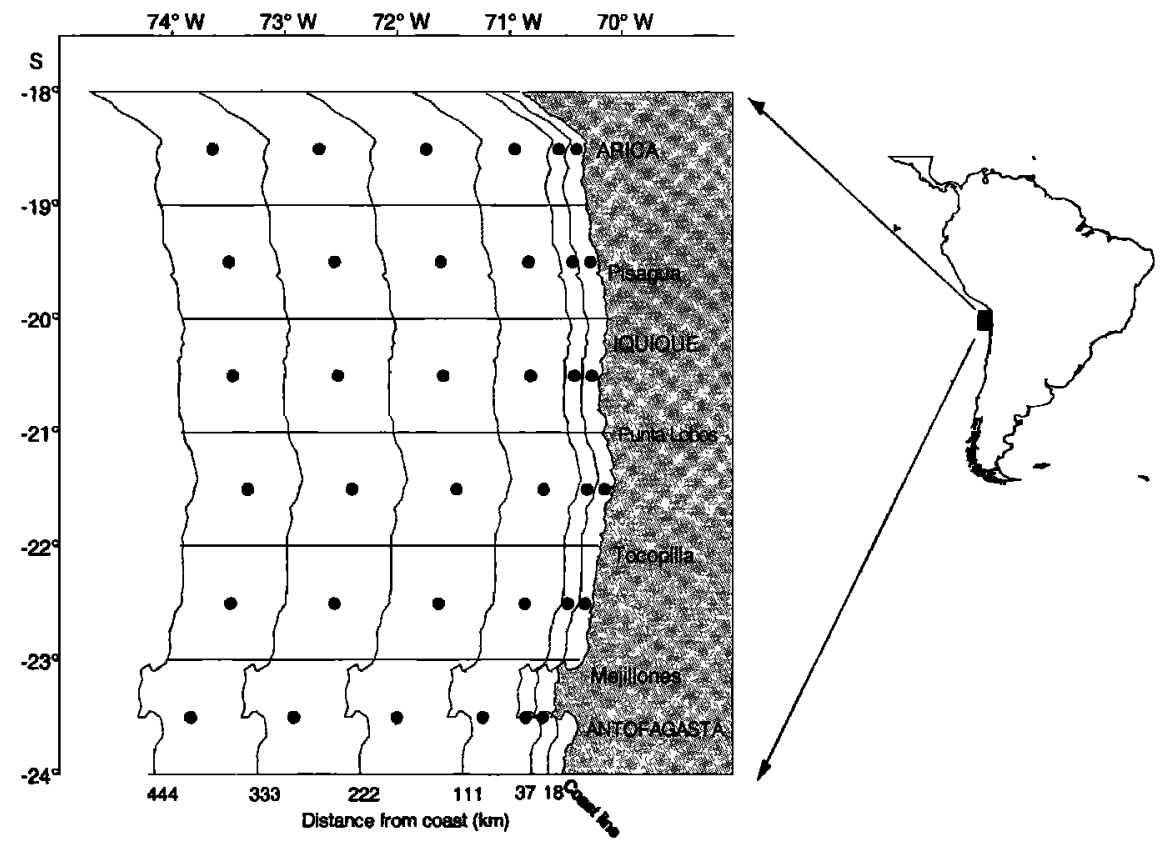

Figure 1. Map of the study region off the north coast of Chile showing the spatial grid for climatology calculations and major cities. Points indicate the center of each grid cell.

disruptions by interannual and interdecadal climate variability, exacerbated by extreme fishing pressure. For instance, the anchovy catch off northern Chile has usually fluctuated between 0.5 and 2.0 MMT since 1986 but fell to $0.18 \mathrm{MMT}$ in 1987 and $0.14 \mathrm{MMT}$ in 1998, 2 years influenced by $\mathrm{El}$ Niño conditions [IFOP, 1998, 1999]. Thomas et al. [2001] show the extreme changes in vertical temperature structure and surface chlorophyll patterns in this region associated with the 1996-1998 La Niña and El Niño events. The climatology presented here quantifies the mean physical environment associated with this variability and provides a baseline against which to calculate anomalies and quantify future changes.

Few of the previous studies of this overall region include information on the mesoscale structure of either wind forcing or oceanic conditions in the Chilean coastal ocean. Wind forcing for the larger-scale Peru-Chile Current system (and other eastern boundary currents) is presented by Bakun and Nelson [1991]. Their seasonal climatology is constructed from merchant ship observations, binned into $1^{\circ}$ squares. This spatial scale is too large to represent the nearshore winds over the narrow shelf, which at these low latitudes are modified by strong land-sea temperature differences. The Bakun and Nelson climatology agrees with other observations in suggesting that the wind forcing weakens as one moves north toward the change in coastal orientation at the border of Peru and Chile. It does not represent the seasonal maximum very well, however, finding a maximum in winter (June-September) off northern Chile $\left(20^{\circ}\right.$. $24^{\circ} \mathrm{S}$ ). A 10 year climatology of alongshore wind stress calculated from European Centre for Medium-Range Weather Forecasts (ECMWF) winds [Thomas, 1999] indicates a springsummer maximum between $20^{\circ}$ and $25^{\circ} \mathrm{S}$, although these data also suffer from a coarse grid scale. Coastal wind measurements presented by Shaffer et al. [1997, 1999] indicate a clear springsummer maximum in alongshore wind stress at $30^{\circ} \mathrm{S}$ consistent with the spring and summer seasonal maximum reported by others [Fuenzalida, 1989; Pizarro et al., 1994].
Brandhorst [1971] combined data from two cruises (FebruaryMarch) to describe the oceanic circulation between $15^{\circ}$ and $42^{\circ} \mathrm{S}$ in the summer of one year (1960). He observed equatorward surface flow in the $100 \mathrm{~km}$ next to the coast and beginning 200$300 \mathrm{~km}$ offshore. In between these equatorward currents, a poleward surface countercurrent extended from $19^{\circ}-35^{\circ} \mathrm{S}$. Other authors have referred to an offshore poleward surface current off Peru as the Peru-Chile Countercurrent, but there is less agreement about its existence and location off Chile [Fonseca, 1989; Strub et al., 1995]. Below the surface, Brandhorst showed a poleward undercurrent next to the continental slope from $15^{\circ}$ to $40^{\circ} \mathrm{S}$ carrying salty water with extremely low oxygen concentrations to the south. This feature was observed previously off Peru and northern Chile by Gunther [1936] and others. Station spacing off northern Chile was about $1^{\circ}$, with an extra station included near the coast. Brandhorst drew schematic diagrams showing cross-shelf sections, which indicated that upwelling brought water from both the undercurrent and from an offshore salinity minimum to the surface off northern Chile. Although this analysis provided no seasonal information and poorly resolved the region within $100 \mathrm{~km}$ of the coast, the essential features described by Brandhorst [1971] are those most often found in later studies.

Inostroza [1972] attempted to construct a seasonal atlas using the data available at the time, which consisted of only 36 cruises between 1875 and 1968. The data covered parts of the Chilean coast from $18^{\circ}$ to $50^{\circ} \mathrm{S}$ in $1^{\circ}$ boxes. The fields again showed the essential features of the upwelling system in the north (described above), but the picture in each season at each location was often determined by only one or a few measurements, resulting in very noisy fields. Silva and Fonseca [1983], Bernal et al. [1982], and Fonseca [1989] used selected cruises to characterize the circulation off the northern half of Chile as composed of alternating bands of equatorward and poleward flow. These are somewhat similar to those found by Brandhorst [1971], although Bernal et al. describe five or more bands. Fonseca [1989] depicts 
the poleward surface flow between 100 and $300 \mathrm{~km}$ offshore as maximum in summer and present year-round, but the small number of cruises used (six) makes this conclusion tentative.

A more recent atlas by Rojas and Silva [1996] provides monthly fields of temperature, salinity and oxygen at various depths for the region between $18.5^{\circ} \mathrm{S}$ and $50^{\circ} \mathrm{S}$, again using $1^{\circ}$ bins. These data come from nearly 200 cruises, most between 1957 and 1995, but still provide only a coarse view of the region next to the coast. Despite the greater number of observations the use of monthly averages produces fields that continue to be noisy. The offshore surface temperature and salinity fields are very similar to the surface fields we present here, although the fields next to the coast lack the strong cross-shelf gradients found in our fields. Some of the results from the $100 \mathrm{~m}$ depth fields from Rojas and Silva are summarized in section 4.

Within the existing data set used by Rojas and Silva [1996], the greatest data density is found in the region off northern Chile. This area has been systematically monitored by the Chilean national Fisheries Institute (Instituto de Fomento Pesquero (IFOP)) because of its economic value. The available IFOP database extends over 30 years (1964-1996) and makes this one of the few regions within the Peru-Chile Current system where the construction of a relatively reliable climatology is possible. Here we use this database to present the seasonal climatology on spatial scales small enough to resolve the relatively narrow region of upwelling near the coast. The hydrographic data are supplemented by climatological meteorological and tide gauge data from coastal stations, which serve as a link between offshore hydrography and coastal processes. In a companion paper (J.L. Blanco et al., Hydrographic conditions off northern Chile during the $1996 \mathrm{La}$ Nina and the 1997-1998 El Nino, submitted to Journal of Geophysical Research, 2000, hereinafter referred to as Blanco et al., submitted manuscript, 2000), the climatology presented here is used to quantify physical variability during the strong 1997 1998 El Niño.

We have organized the paper as follows: In section 2 we present details of the historical data set, data collection protocols, and the gridding methods used for presentation of the data. The climatological seasonal cycles are presented in section 3, first for three coastal meteorological and tide gauge stations, then for water mass properties in the study area, and lastly for the hydrographic fields. Section 4 discusses the results in light of other observations in this region, the greater Chile-Peru Current system and in the somewhat similar California Current. Section 5 provides a brief summary.

\section{Data and Methods}

\subsection{Hydrographic Data}

The hydrographic data used to calculate this climatology were collected by IFOP in the upwelling region off northern Chile (Figure 1). A total of 4740 stations, sampled between 1964 and 1996 (Figure 2) and taken between $18^{\circ} \mathrm{S}$ and $24^{\circ} \mathrm{S}$ and within $440 \mathrm{~km}$ of the coast $\left(\sim 74^{\circ} \mathrm{W}\right)$, were used. Figure 2 shows that sampling was remarkably consistent temporally, with the exception of the period in the mid-to late 1970s. Spatially, station sampling is representative of the area in Figure 1, with greatest sampling density within $\sim 200 \mathrm{~km}$ of the coast and in the northern portion of the study area. Quality control of the data was subjective. For each grid point, all profiles were examined visually. Only those with obvious deviations from expected trends, such as density inversions, were removed. Profiles from El Niño periods were purposely not filtered from our data set. Approximately $3 \%$ of the original profiles were eliminated by

a)

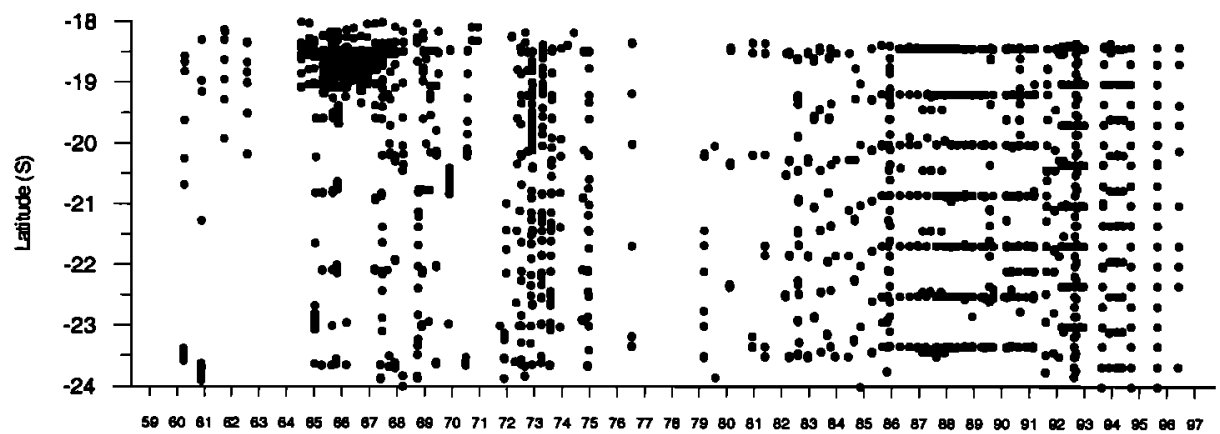

Years

b)

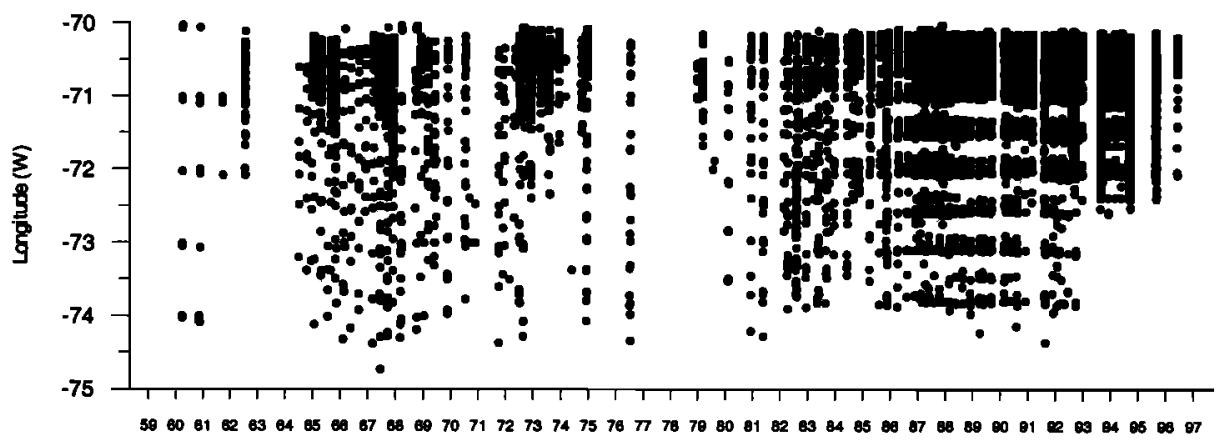

Years

Figure 2. (a) Time-latitude and (b) time-longitude distribution of hydrographic stations making up the historical database for the north of Chile. 
this screening. Although errors of both inclusion and exclusion were undoubtedly made, the number of stations available minimizes the biases in the climatological means presented here.

From 1964 to 1991, samples were obtained using Nansen or Niskin bottles with calibrated reversing thermometers. Salinity and oxygen were measured from discrete samples taken from standard depths. Salinity was measured with Autolab induction salinometers. Oxygen concentrations were obtained by Winkler titration and included the modification of Carpenter [1965] after 1967. Beginning in 1992, temperature and salinity were obtained using either a Neil Brown MK 3 or a Sea Bird (model 19) conductivity-temperature-depth probe (CTD). The CTDs are calibrated every 2 years, and data from individual cruises are validated with reversing thermometers and salinity samples. Oxygen concentrations continued to be determined by laboratory analysis of water samples throughout the period.

The spatial grid used to bin and average the data was designed to balance two conflicting requirements: (1) the inclusion of sufficient stations to calculate a realistic mean and (2) the retention of sufficient resolution to resolve the strong cross-shelf gradients within $40 \mathrm{~km}$ of the coast. Traditional $1^{\circ}$ grid squares do not provide sufficient resolution near the coast, but the latitudinal separation between the most consistently occupied transects did not allow formation of a square $0.5^{\circ}$ grid. The spatial grid used here has $1^{\circ}$ resolution in latitude and a varying longitudinal (cross-shelf) dimension (Figure 1), based on distance from shore. The grid cell closest to the coast has an offshore boundary at $19 \mathrm{~km}$, and these increase offshore to 37 , $111,222,333$, and $444 \mathrm{~km}$. This distribution attempts to maximize the number of stations contributing to the average values of each season at each spatial point [Blanco, 1996]. Table 1 shows the number of stations contributing to the climatological values of each season, in each grid cell, using surface temperature as an example. Samples for salinity were $\pm 10 \%$ of these values.

Hydrographic data were averaged in time, within the grid, to construct a seasonal climatology of temperature, salinity, and dissolved oxygen. The definition of seasons used here is summer (January-March), fall (April-June), winter (JulySeptember), and spring (October-December). Vertical data within each grid cell were interpolated to 13 standard depths $(0$, $10,25,50,75,100,125,150,200,250,300,400$, and $500 \mathrm{~m}$ ) before averaging, maximizing resolution in the upper water column. Density variables and geopotential anomalies were calculated in each bin from the averaged temperature and salinity profiles for each season.

An analysis of the expected error associated with the gridded means was carried out. Our purpose was to evaluate the confidence with which the patterns of hydrography (temperature, salinity, and oxygen contour intervals of $1.0^{\circ} \mathrm{C}, 0.1$ practical salinity units (psu), and $1.0 \mathrm{~mL} \mathrm{~L} \mathrm{~L}^{-1}$ respectively) should be interpreted. Standard errors, $S_{x}=s / n^{1 / 2}$, where $s$ is the standard deviation and $n$ is the number of stations, were calculated of temperature and salinity in each grid cell and season for surface spatial fields and of temperature, salinity, and oxygen for the three cross-shelf vertical sections used to characterize the climatological subsurface structure. Standard errors which approach the contour interval suggest that the hydrographic parameter at that particular grid cell might be shifted by one interval because of uncertainty. Spatially and temporally coherent patterns across many grid cells of standard error at the same magnitude as the contour interval call into question the entire local pattern associated with the contours and hence their
Table 1. Number of Surface Temperature Stations Contributing to the Climatological Mean in Each Grid Cell of Figure 1 for Each Season ${ }^{\mathrm{a}}$.

\begin{tabular}{|c|c|c|c|c|c|}
\hline \multirow[b]{2}{*}{1} & \multirow[b]{2}{*}{2} & \multicolumn{2}{|c|}{ Grid Position $^{b}$} & \multirow[b]{2}{*}{5} & \multirow[b]{2}{*}{6} \\
\hline & & 3 & 4 & & \\
\hline & & \multicolumn{3}{|c|}{ Summer } & \\
\hline \multirow{7}{*}{$\begin{array}{l}12 \\
15 \\
11 \\
0 \\
2 \\
4\end{array}$} & 29 & 38 & 38 & 16 & 37 \\
\hline & 29 & 25 & 13 & 36 & \\
\hline & 21 & 36 & 39 & 18 & 45 \\
\hline & 4 & 22 & 25 & 13 & 35 \\
\hline & 5 & 24 & 30 & 12 & 25 \\
\hline & 11 & 21 & 24 & 16 & 28 \\
\hline & & \multicolumn{3}{|c|}{ Fall } & \\
\hline \multirow{7}{*}{$\begin{array}{l}12 \\
8 \\
6 \\
6 \\
6 \\
4\end{array}$} & 36 & 36 & 35 & 14 & 48 \\
\hline & 19 & 20 & 20 & 17 & 38 \\
\hline & 22 & 40 & 40 & 16 & 57 \\
\hline & 15 & 28 & 23 & 15 & 39 \\
\hline & 8 & 25 & 25 & 17 & 32 \\
\hline & 13 & 30 & 32 & 20 & 33 \\
\hline & & \multicolumn{2}{|c|}{ Winter } & & \\
\hline \multirow{7}{*}{$\begin{array}{l}19 \\
7 \\
6 \\
4 \\
6 \\
7\end{array}$} & 37 & 99 & 121 & 48 & 74 \\
\hline & 25 & 49 & 100 & 47 & 87 \\
\hline & 18 & 55 & 90 & 52 & 101 \\
\hline & 5 & 40 & 79 & 47 & 76 \\
\hline & 12 & 46 & 82 & 48 & 87 \\
\hline & 20 & 50 & 103 & 49 & 84 \\
\hline & & \multicolumn{2}{|c|}{ Spring } & & \\
\hline 14 & 34 & 52 & 52 & 29 & 56 \\
\hline 5 & 15 & 34 & 41 & 20 & 50 \\
\hline 8 & 20 & 46 & 67 & 27 & 70 \\
\hline 3 & 14 & 37 & 44 & 26 & 68 \\
\hline 5 & 11 & 34 & 43 & 23 & 51 \\
\hline 5 & 12 & 37 & 39 & 27 & 47 \\
\hline
\end{tabular}

\footnotetext{
a Within each season, values are arranged geographically from north to south (top to bottom).

${ }^{6}$ Grid positions are from west to east as in Figure 1.
}

subsequent interpretation. For the surface temperature means, the range of $S_{x}$ over all seasons was $0.06^{\circ} \mathrm{C}-0.79^{\circ} \mathrm{C}$, never as large as the contour interval. Only 11 of the total of 144 grid cells ( 4 seasons, 36 cells in each) had values $>0.5^{\circ} \mathrm{C}$. These 11 values were grouped into two locations: in the grid cells farthest offshore where $n$ was relatively low (Table 1 ) and in the upwelling frontal zone during spring and summer, where variance is expected to be greatest. For the surface salinity means, $S_{x}$ ranged from 0.010 to 0.114 . Only 5 of the 144 grid cells had values greater than our 0.1 contour interval. Each of these five were in the grid cells farthest offshore, where $n$ was relatively small. Subsurface temperature $S_{x}$ in the grid cells making up the three cross-shelf vertical sections (three transects $x$ four seasons $\times 71$ depth $/$ space locations $=852$ cells) had a wider total range $\left(0.04^{\circ} \mathrm{C}-2.23^{\circ} \mathrm{C}\right)$ than surface values. Fewer than $5 \%$ of these grid cells, however, actually had values greater than $0.5^{\circ} \mathrm{C}$, and only $0.5 \%$ had values greater than our $1.0^{\circ} \mathrm{C}$ contour interval. Elevated values were located in the grid cells farthest offshore, where $n$ was relatively small and at the depth of the thermocline. Subsurface salinity $S_{x}$ in the grid cells of the three cross-shelf vertical sections had a range of $0.005-0.159$ psu, with fewer than $0.6 \%$ having values $>0.1$ psu. Subsurface oxygen concentration $S_{x}$ in the grid cells of the three cross-shelf vertical sections ranged from 0.02 to $0.73 \mathrm{~mL} \mathrm{~L}^{-1}$, with fewer than $2 \%$ having values $>0.5 \mathrm{~mL} \mathrm{~L}^{-1}$. These analyses suggest that, in general, the climatological means presented here are 
statistically robust and that hydrographic patterns in each season, at the contour intervals chosen, can be interpreted with reasonable confidence. Maximum uncertainty, although still smaller than the contour interval, is present in the most offshore grid cells, where gradients and seasonal variability are weak anyway, and in locations (the upwelling frontal zone and thermocline) where variance due to intraseasonal and interannual variability is expected to be greatest.

\subsection{Time Series at Coastal Stations}

Monthly averages of coastal sea level were obtained from the University of Hawaii Sea Level Center for Arica $\left(18.5^{\circ} \mathrm{S}\right)$ and Antofagasta $\left(23.5^{\circ} \mathrm{S}\right)$ (see Figure 1). These data are available for the period January 1975 to April 1998. Climatological monthly means were calculated after correcting for the inverse barometer effect, using atmospheric pressure obtained from the U.S. Climate Analysis Center.

Monthly averages of coastal sea surface temperature (SST) were calculated from data measured daily at the two tide gauge stations mentioned above and a third station at Iquique $\left(20.5^{\circ} \mathrm{S}\right)$ (see Figure 1). These data were provided by the Naval Hydrographic Service (Servicio Hidrografico y Oceanografico de la Armada de Chile (SHOA)) for the period 1960-1997.

Climatological monthly averages of wind speed and direction were calculated from daily measurements at the airport meteorological stations of Arica, Iquique, and Antofagasta for the period 1970 to 1997 . These data were provided by the Chilean meteorological service, Direccion Meteorologica de Chile. The measurement taken at $1500 \mathrm{LT}$ was used, as it corresponds to the maximum wind intensity of the daily cycle and presents maximum persistence in speed and direction [Pizarro et al., 1994]. The northem Chilean coastline is oriented approximately north-south, and here we refer to the north-south wind component as the alongshore wind at each location.

\section{Results}

\subsection{Coastal Time Series}

Monthly climatological means of the annual cycle of sea level, SST, and wind velocity at the three coastal stations (Arica, Iquique, and Antofagasta) are presented in Figure 3. At all three locations alongshore wind velocities (Figure $3 c$ ) are maximum $\left(4.2-6.2 \mathrm{~m} \mathrm{~s}^{-1}\right)$ in austral late spring to summer (DecemberMarch) and minimum (2.6-4.0 m s$)$ in austral winter (JuneJuly). The cross-shore winds have a similar cycle but are weaker and have a much smaller seasonal range (Figure $3 \mathrm{~d}$ ). The alongshore component is equatorward and therefore upwellingfavorable throughout the year in these climatological monthly means. Daily data (not shown) indicate that poleward winds (downwelling favorable) do occur in winter with timescales of several days and with a latitudinal dependence, occurring more often at Antofagasta than at Iquique and almost never at Arica. Poleward winds are seldom seen in the monthly averages from individual years and do not appear in the climatological monthly seasonal cycles. The magnitudes of the winds (and other coastal variables) may be affected by specific local siting factors, such as height of measurement, elevation of the airport, etc., so offsets between the different stations should be interpreted with caution. Despite this, the weaker alongshore wind strength at the most northern station (Arica) is believed to reflect a true decrease in wind forcing in the corner of the large bight formed by the change in coastal orientation at the northern Chilean border.

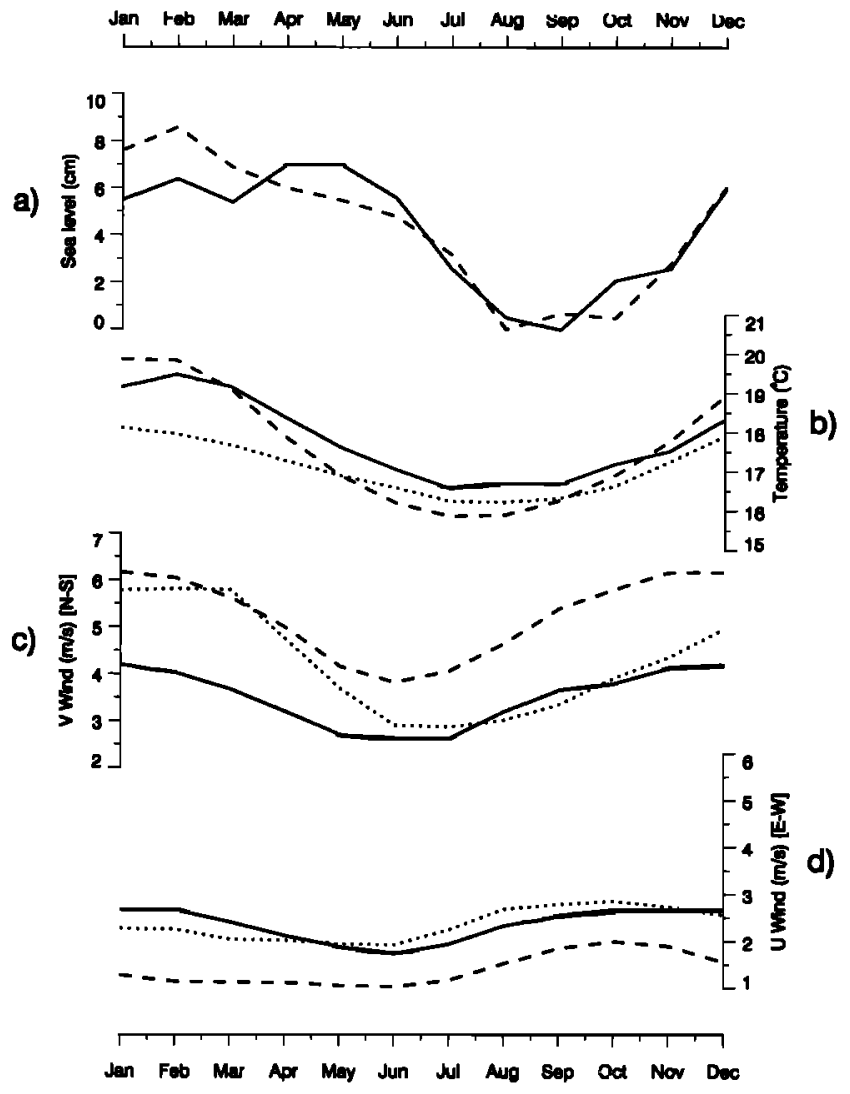

Figure 3. Monthly climatologies from coastal stations at Arica (solid line), Iquique (dotted line) and Antofagasta (dashed line) of (a) sea level (Arica and Antofagasta only), (b) sea surface temperature, (c) alongshore wind velocity, and (d) cross-shore wind velocity.

Comparison of the relative magnitudes of the two wind components shows that the alongshore wind is strongly dominant in each month at Antofagasta, but is clearly dominant only in summer-fall at Iquique. At the northern extreme of the study area (Arica), alongshore wind is only marginally stronger than the cross-shelf component throughout the year. The magnitude of the seasonal cycle of alongshore wind is least at Arica (annual range of $\left.\sim 1.6 \mathrm{~m} \mathrm{~s}^{-1}\right)$, greater at Antofagasta $\left(2.4 \mathrm{~m} \mathrm{~s}^{-1}\right)$, and greatest at Iquique $\left(2.9 \mathrm{~m} \mathrm{~s}^{-1}\right)$, in the center of the study domain. Also, at Iquique the minimum and maximum in alongshore wind speeds appear to both last longer than at the other stations and to begin later in the year. A large-scale study of coastal winds off South America [Bakun and Nelson, 1991] indicates maximum equatorward winds in austral winter (June-September), when the Intertropical Convergence Zone (ITCZ) has moved farthest north. The winds presented here make it clear that the maximum in upwelling-favorable winds occurs in austral summer off northem Chile, even at the northern border. These conflicting results are most likely due to differences in sampling and averaging. The Bakun and Nelson data are from ships, averaged to a $1^{\circ}$ grid, and are more representative of offshore conditions. Given the very narrow upwelling region and strong land-sea thermal contrasts at these low latitudes, we expect the airport wind measurements at the coast to be more relevant to coastal ocean processes.

Sea surface temperature (Figure 3b) at the coastal stations is in phase with the annual cycle of solar heating (maximum in 
ARICA [ $\left.18^{\circ} 30^{\prime} \mathrm{S}\right] \quad$ IQUIQUE [ $\left.20^{\circ} 30^{\prime} \mathrm{S}\right] \quad$ ANTOFAGASTA [ $\left.23^{\circ} 30^{\prime} \mathrm{S}\right]$

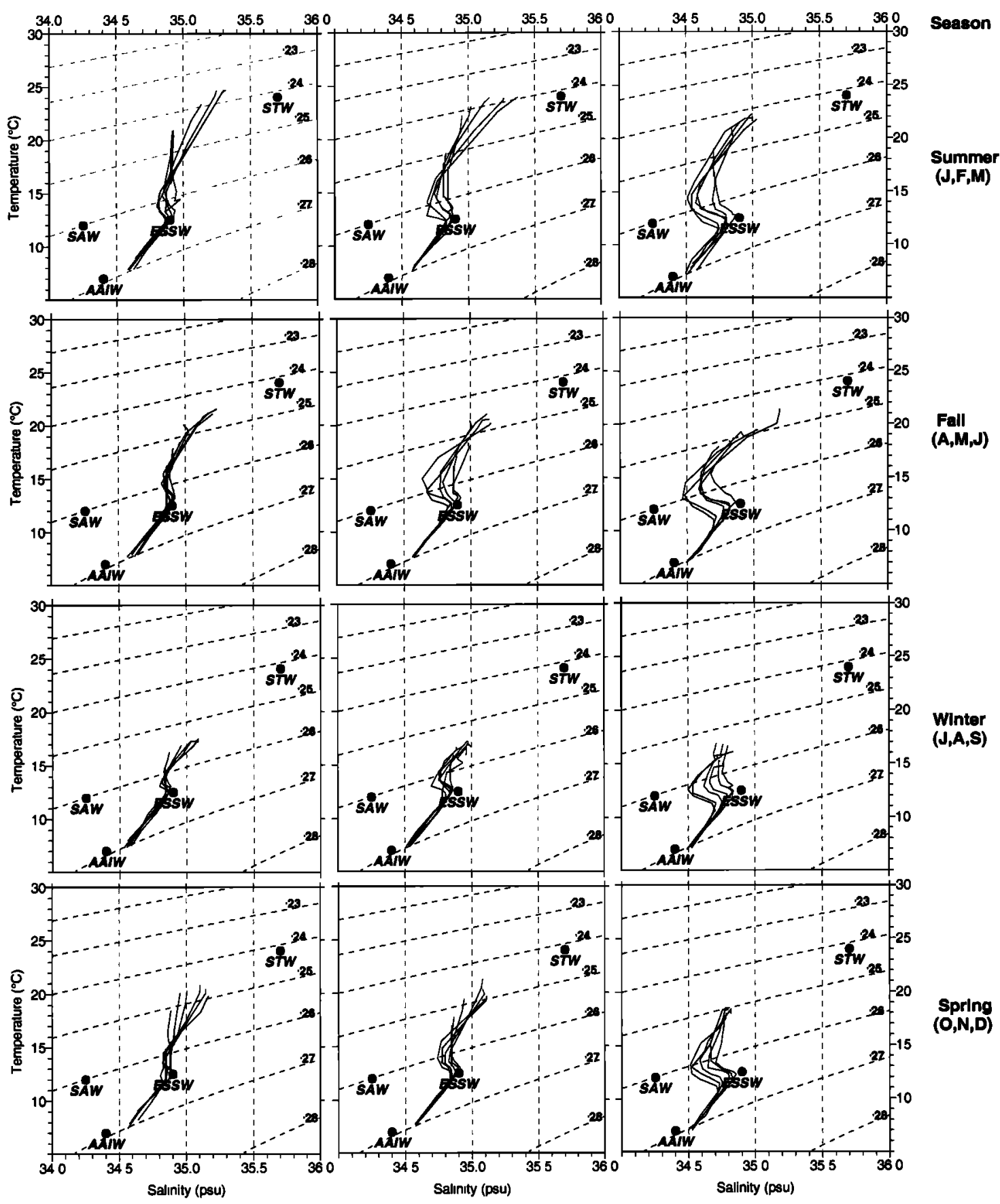

Figure 4. Seasonal climatological $T-S$ diagrams for three regions in the north of Chile. The multiple curves represent the six grid distances from the coast (Figure 1), illustrating cross-shelf variability. Dots indicate characteristics of source water (STW is subtropical water, SAW is subantarctic water, ESSW is equatorial subsurface water, and AIW is Antarctic intermediate water).

summer). It is similar to the annual cycle of wind but lags the alongshore wind component by $\sim 1$ month, with minimum SST $\left(15.2^{\circ}-16.0^{\circ} \mathrm{C}\right)$ in July-September and maximum SST $\left(18.0^{\circ}-\right.$ $20.5^{\circ} \mathrm{C}$ ) in January-February. This type of lag may be caused by the onset of upwelling, which keeps SST low as winds increase in spring, before seasonal heating overpowers the upwelling. At more temperate latitudes, upwelling can even move the minimum into late spring or early summer [Strub et al., 1987].
Seasonal variability in SST is maximum at Antofagasta and minimum at Iquique. Whether this is due to Iquique's stronger seasonal wind signal and slightly longer upwelling season or to the interaction of coastal orientation (Antofagasta's unique cape structure) and/or bathymetry (there is a widening of the shelf around and south of Iquique) with wind forcing and resultant circulation is not known.

Annual cycles of coastal sea level are only available at the 
Table 2. Water Mass Characteristics ${ }^{a}$

\begin{tabular}{lllll}
\hline Water Mass & Depth Range, $\mathrm{m}$ & Temperature, ${ }^{\circ} \mathrm{C}$ & Salinity, psu & Oxygen, $\mathrm{mL} \mathrm{L}^{-1}$ \\
\hline STW & "surface" & $>18.5$ & 34.9 & $>5$ \\
& $0-40$ & $17.0-25.0$ & $34.9-35.7$ & $>5$ \\
& & 24.0 & 35.7 & \\
SAW & $25-40$ & $11.5-14.5$ & $34.1-34.8$ & $2.5-4.5$ \\
& $40-80$ & $11.0-14.0$ & $34.3-34.8$ & $3.0-6.0$ \\
& & 12 & 34.25 & \\
ESSW & $300-350$ & $9.5-10.5$ & $34.6-34.8$ & $0.25-0.5$ \\
& $100-300$ & $11-13$ & $34.7-34.9$ & $0.25-1.0$ \\
& & 12.5 & 34.9 & \\
AIW & $>500(710-750)$ & 5.5 & 34.5 & $1.5-1.9$ \\
& see text below & $6-8$ & 734.5 & $1.5-2.5$ \\
& & 7 & 34.4 &
\end{tabular}

\begin{abstract}
STW is subtropical water, SAW is subantarctic water, ESSW is equatorial subsurface water, and AIW is Antarctic intermediate water. The first line of each water mass description provides the characteristic depth range, temperature, salinity, and oxygen concentration values for the major water masses observed throughout the Chilean coast by Bernal et al. [1982]. The second line provides the ranges actually observed in our study area. The third line provides the values we have used to characterize each water mass end-member and plotted in Figure 4 as a reference point against which seasonal changes can be viewed. AIW was not sampled in this study; it is generally found below 500 $\mathrm{m}$ with a core between 710 and $750 \mathrm{~m}$.
\end{abstract}

northern and southern ends of the study region (Figure 3a). Seasonal maxima in sea levels are caused by heating and expansion of the water column in summer. Minimum sea levels lag those of temperature by 1-2 months, with lowest values in late austral winter and early spring (August-October). This lag may be the result of the alongshore equatorward currents that intensify in spring, with a cross-shelf geostrophic slope that serves to keep coastal sea levels low. Summer maximum values occur in February at Antofagasta as a clear annual maximum. Elevated annual sea levels at Arica are sustained over an extended period through summer and fall (December-May), with maximum values later in the annual cycle (April-May).

\subsection{Water Masses}

$T-S$ diagrams provide an introduction to hydrographic patterns and circulation, focusing on the seasonal and spatial variation in the distribution of water masses. Seasonal climatological $T-S$ diagrams from profiles offshore of Arica, Iquique, and Antofagasta are shown in Figure 4. Table 2 presents the characteristics for each of the water masses which are present (or influence water properties) in the study area: subtropical water (STW), subantarctic water (SAW), equatorial subsurface water (ESSW), and Antarctic intermediate water (AIW). Table 2 shows characteristic depth ranges, salinities, temperatures, and oxygen concentrations from previously published observations of these water masses along the entire Chilean coast [Bernal et al., 1982], ranges of values observed within the data set analyzed here, and a reference $T-S$ value chosen to represent the end-member characteristics of each water mass (plotted in Figure 4). This latter value is not intended to define far-field source water characteristics but simply to provide a constant reference point for comparison of water mass influences between seasons, transects, and cross-shelf profiles.

The observed patterns in $T-S$ result from equatorward flow of relatively cold and fresh water at middepths offshore (SAW) and below $500 \mathrm{~m}$ (AIW) and the poleward transport of equatorial water at the surface (STW) and at middepths (ESSW) in the poleward undercurrent. Although the $T-S$ curves differ with season and location, the vertical sequence of the water masses is conserved. STW occurs at the surface (with an absolute salinity maximum), followed by SAW (the relative salinity minimum), then ESSW (the relative salinity maximum), finally moving toward AIW (the absolute temperature and salinity minimum). Most variability occurs in the upper $150 \mathrm{~m}$ (above and in the relative salinity minimum), corresponding to changes in STW and SAW. In the discussion, we speculate on the possible influence of freshwater coastal runoff from higher latitudes on this salinity minimum. To a lesser degree, there are significant changes in the signature of ESSW (near the relative salinity maximum). Deeper water mixing toward AIW properties undergoes almost no change in its $T-S$ values between seasons.

STW appears as the warm, saline water at the top of the $T-S$ curves. Strongest influences of STW are found offshore (100 $\mathrm{km}$ and farther) at the surface in spring, summer, and fall off Arica and Iquique, but only in summer and fall off Antofagasta. ESSW is found at middepth, carried by the poleward undercurrent and characterized by a relative salinity maximum and an oxygen minimum (Table 2). The relative maxima caused by ESSW become warmer and saltier moving from offshore to onshore, suggesting a concentration of the poleward undercurrent next to the coast (easiest to see at Antofagasta). In addition, the $T-S$ curves show that the influence of ESSW characteristics increases at lower latitudes. The SAW overlays the ESSW. Though ESSW is found at all latitudes, the influence of SAW decreases to the north, and the relative salinity minima caused by SAW is very weak at Arica (Figure 4). SAW is most evident in the Antofagasta section, penetrating to $200 \mathrm{~km}$ from the coast in spring and summer above $120 \mathrm{~m}$, suggesting relatively strong equatorward flow in the southern part of the study area. The AIW can only be indirectly inferred from the decrease in salinity and increase in oxygen concentration below $250 \mathrm{~m}$, because the $500 \mathrm{~m}$ profiles do not reach the core of AIW (Table 2). Figure 4 shows that the coldest and freshest water is observed below $400 \mathrm{~m}$ off Antofagasta and indicates that the influence of the AIW decreases moving equatorward. 


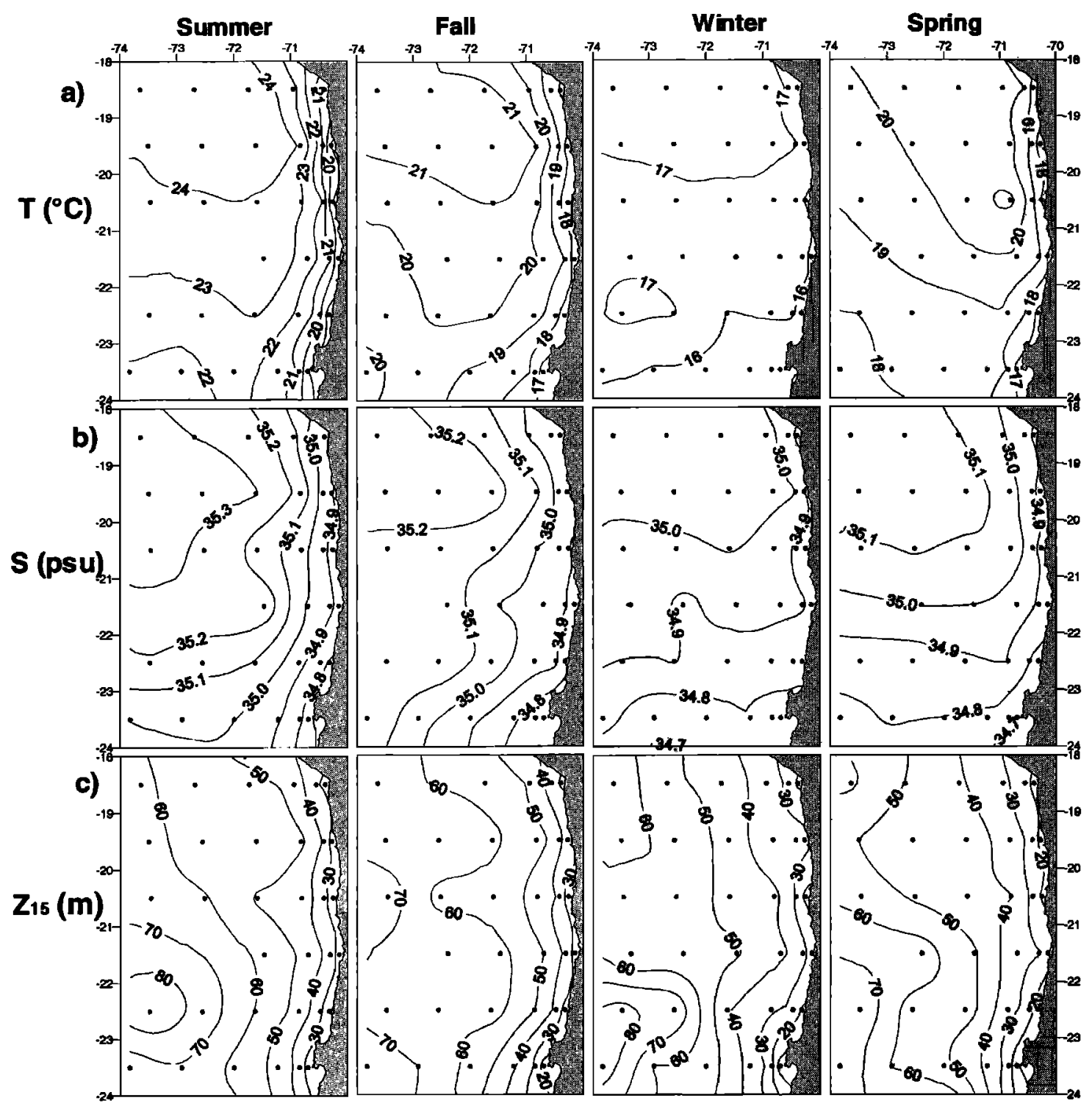

Figure 5. Seasonal climatologies of (a) sea surface temperature (SST), (b) surface salinity (S), and (c) $15^{\circ} \mathrm{C}$ isotherm depth $\left(Z_{15}\right)$.

\subsection{Spatial Patterns}

Climatological seasonal patterns of surface temperature, surface salinity, and the depth of the $15^{\circ} \mathrm{C}$ isotherm for northern Chile are shown in Figure 5. Surface temperature and salinity have strong annual cycles with maximum offshore values in the summer $\left(>24^{\circ} \mathrm{C}\right.$ and $\left.35.3 \mathrm{psu}\right)$ and minimum values during winter $\left(16^{\circ}-17^{\circ} \mathrm{C}\right.$ and $\left.34.8-35.0 \mathrm{psu}\right)$. Within $100 \mathrm{~km}$ of the coast, isopleths are generally parallel to the shore even during winter because of upwelling of cooler, less saline water via the permanent upwelling-favorable wind forcing. This upwelling moderates the annual cycle of both temperature and salinity near shore. Within $100 \mathrm{~km}$ of the coast, summer minimum temperatures and salinities are $19^{\circ}-20^{\circ} \mathrm{C}$ and $34.8-34.9 \mathrm{psu}$, respectively, and winter values are $16^{\circ}-17^{\circ} \mathrm{C}$ and $34.8-34.9 \mathrm{psu}$. The cross-shelf gradients of both temperature and salinity, which are maximum in summer, decrease from north to south in all seasons, reflecting the decreasing influence of offshore equatorial surface water properties. Offshore of the coastal upwelling region (west of $\sim 72^{\circ} \mathrm{W}$ ) isopleths of temperature and salinity are zonally oriented, consistent with latitudinal gradients in solar heating. The $15^{\circ} \mathrm{C}$ isotherm is deepest offshore and slopes upward toward the coast in all seasons, reflecting the year-round upwelling. The isotherm is $<30 \mathrm{~m}$ deep at the coast in all seasons and deepens to $>70 \mathrm{~m}$ at the western edge of the study area. The distance from shore of the $40 \mathrm{~m}$ isoline provides an indication of the seasonal variability in the subsurface slope of isotherms upwards towards the coast, with minimum crossshelf distances (maximum slope) in summer and fall, and maximum cross-shelf distances (minimum slope) in winter and spring. This cycle is most pronounced at the northern and southern extents of the study area and is minimum in the center between $21.5^{\circ}$ and $22.5^{\circ} \mathrm{S}$. This is consistent with the weaker annual range in coastal SST at Iquique (Figure $3 \mathrm{~b}$ ).

Climatological seasonal geostrophic flow off northern Chile is shown in Figure 6 as patterns of geopotential anomaly (equivalent to dynamic height) integrated over the upper water column ( 0 to $500 \mathrm{dbar}$ ) and for the subsurface region (200 to 500 dbar). Flow at the surface (Figure 6a) is generally equatorward 


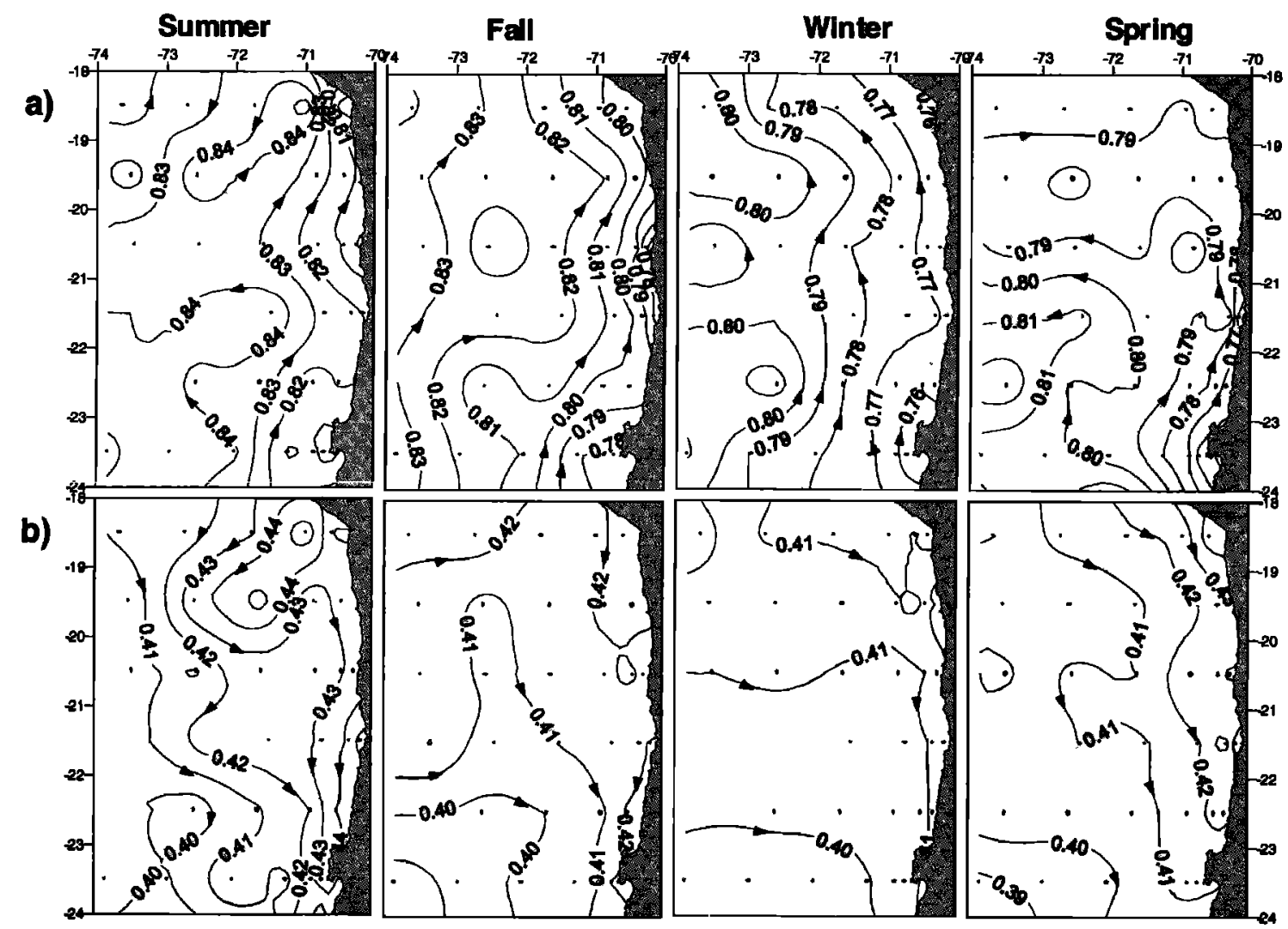

Figure 6. Seasonal climatologies of geopotential anomaly $(\Delta \Phi)$ for (a) surface relative to $500 \mathrm{dbar}$ and (b) $200 \mathrm{dbar}$ relative to $500 \mathrm{dbar}$.

throughout the year because of low dynamic heights along the coast resulting from the equatorward winds and offshore Ekman transport. Within $200 \mathrm{~km}$ of the coast the equatorward current is strongest in fall and a latitudinal difference in the seasonal cycle is present. South of $\sim 20^{\circ} \mathrm{S}$, coastal flow is strongly equatorward throughout the year, with a maximum in fall centered at $21^{\circ} \mathrm{S}$. North of $20^{\circ} \mathrm{S}$, a stronger seasonal cycle is evident. Flow is equatorward in summer, fall, and winter but becomes weak in spring and has a zonal, onshore orientation. Subsurface flow at $200 \mathrm{~m}$ (Figure 6b) shows the poleward undercurrent, which is strongest in summer and weakest in winter. The undercurrent appears more organized and consistent in the southern portion of the study area (south of $\sim 21^{\circ} \mathrm{S}$ ). In all seasons, there appears to be an onshore component of flow at $200 \mathrm{~m}$, strongest in fall and winter.

\subsection{Vertical Structure}

The seasonal cross-shelf vertical structure $(0-500 \mathrm{~m})$ of temperature, salinity, and oxygen are presented in Figures 7, 8, and 9 for transects extending $400 \mathrm{~km}$ offshore of Arica, Iquique, and Antofagasta. Temperature structure (Figure 7) shows that vertical stratification is maximum in summer at each location and weakest in winter. Of the three locations, surface stratification in winter is strongest at Arica, the northernmost transect. At each location, near-surface isotherms $\left(>14^{\circ} \mathrm{C}\right)$ tilt upward toward the coast throughout the year, in response to the continuous upwelling-favorable winds. Below $150 \mathrm{~m}$, isotherms deepen as they approach the coast, indicative of poleward geostrophic flow associated with the undercurrent. This pattern is present throughout the year at Antofagasta but disappears or is weak in winter at the two more northern transects. The crossshelf slope of the $12^{\circ} \mathrm{C}$ and $13^{\circ} \mathrm{C}$ isotherms provides an indication of the transition from upper water column coastal upwelling (and equatorward flow) to subsurface poleward flow and provides an indicator of latitudinal and seasonal variability. The $12^{\circ} \mathrm{C}$ isotherm is deepest at Arica and becomes progressively shallower at the transects farther south in all seasons. The depth of the $12^{\circ}$ isotherm at the coast (and the overall slope of the isotherm between $400 \mathrm{~km}$ offshore and the coast) is largest in summer ( $275 \mathrm{~m}$ at Arica) and least in winter (190 $\mathrm{m}$ at Arica), except at Antofagasta, where its minimum depth is in spring. This implies a general maximum in the strength of the poleward undercurrent in summer.

Vertical salinity structure (Figure 8 ) is determined by the distributions of the four principal water masses in the region. The freshest water mass in the study area is influenced by AIW, evident as a salinity minimum at depth. Between 100 and $300 \mathrm{~m}$ adjacent to the coast, ESSW creates a relative salinity maximum. A relative salinity minimum located above and offshore of ESSW is modified SAW. Highest salinities are found offshore in STW. This most saline water ( $>35.1 \mathrm{psu}$ ) is present in the surface water offshore in summer and fall and is seen as a wedge of warm, saline water at the surface extending southward and toward the coast, with minimum penetration in winter (Figures 7 and 8). Salinities in the upper $50 \mathrm{~m}$ indicate that upwelling brings lower salinity water to the surface near the coast throughout the year but is weakest in winter at all three transects. Upwelled water is either ESSW (from the undercurrent) or SAW 


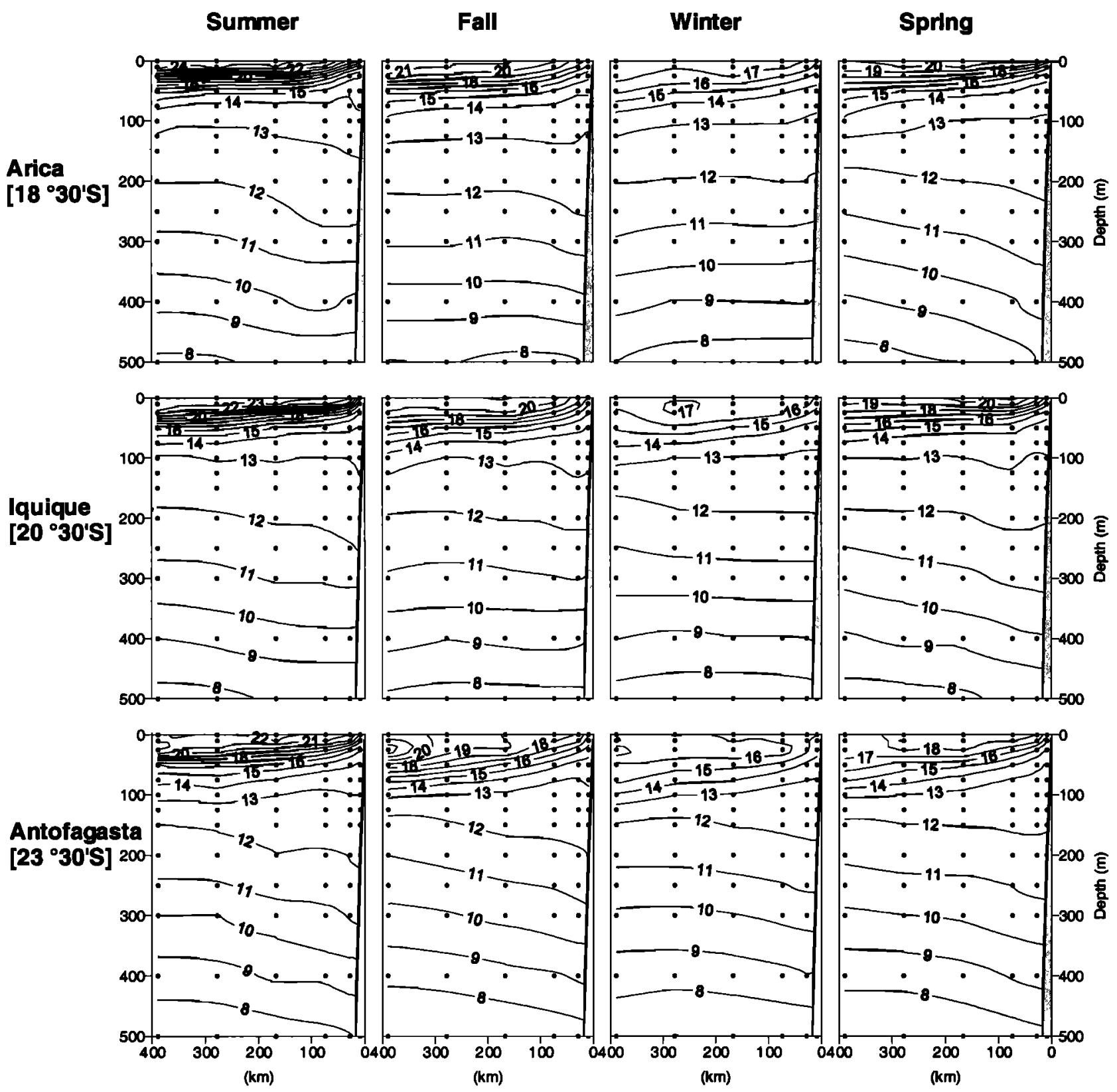

Figure 7. Seasonal climatologies of cross-shelf vertical temperature structure $\left({ }^{\circ} \mathrm{C}\right)$ at Arica, Iquique, and Antofagasta.

(from just offshore of the undercurrent) or a combination of the two. Between 50 and $150 \mathrm{~m}$, a tongue of low-salinity SAW water $(<34.7)$ is present in the seaward portion of the southern and central transects, extending from offshore and the south toward the coast (Figure 8), but is weak or nonexistent in the Arica transects. The $T-S$ diagrams from Arica (Figure 4) show the relative salinity minimum caused by SAW to be weak but present in all seasons. Salinities within this tongue are lowest at Antofagasta. Seasonally, salinities are lowest at both Antofagasta and Iquique in fall. This is consistent with the stronger onshore flow in the southern half of the domain at $200 \mathrm{~m}$ in summer-fall (Figure 6b). Below $200 \mathrm{~m}$ the depth of the 34.7 isohaline provides a key to seasonal and latitudinal variability in the middepth layer of ESSW. In each season its position becomes shallower with increasing latitude, centered between 350 and $400 \mathrm{~m}$ off Arica, and shoaling to $250-350 \mathrm{~m}$ off Antofagasta, and at each transect this isohaline is shallowest in winter and deepest in summer. One possible explanation of this is an increased poleward flow of ESSW in summer and its stronger influence in the north than in the south, consistent with the summertime maximum in strength for the poleward undercurrent implied from the temperature sections (Figure 7). This trend is also consistent with latitudinal trends in the proportion of ESSW evident in the $T-S$ plots (Figure 4).

The climatological seasonal cycle of cross-shelf vertical oxygen concentrations is presented in Figure 9. A strong vertical gradient is present in the upper $100 \mathrm{~m}$ in all seasons. Oxygen concentrations drop from $>5 \mathrm{~mL} \mathrm{~L}^{-1}$ at the surface to values $<1.0$ $\mathrm{mL} \mathrm{L} \mathrm{L}^{-1}$ below $100 \mathrm{~m}$. Cross-shelf patterns provide clear evidence of continuous upwelling of low oxygen concentration subsurface water near the coast throughout the year at each transect. At the western extent of each transect the depth of the $1.0 \mathrm{~mL} \mathrm{~L}$ isopleth indicates a latitudinal trend in the thickness of the offshore oxygenated surface layer from shallowest in the 


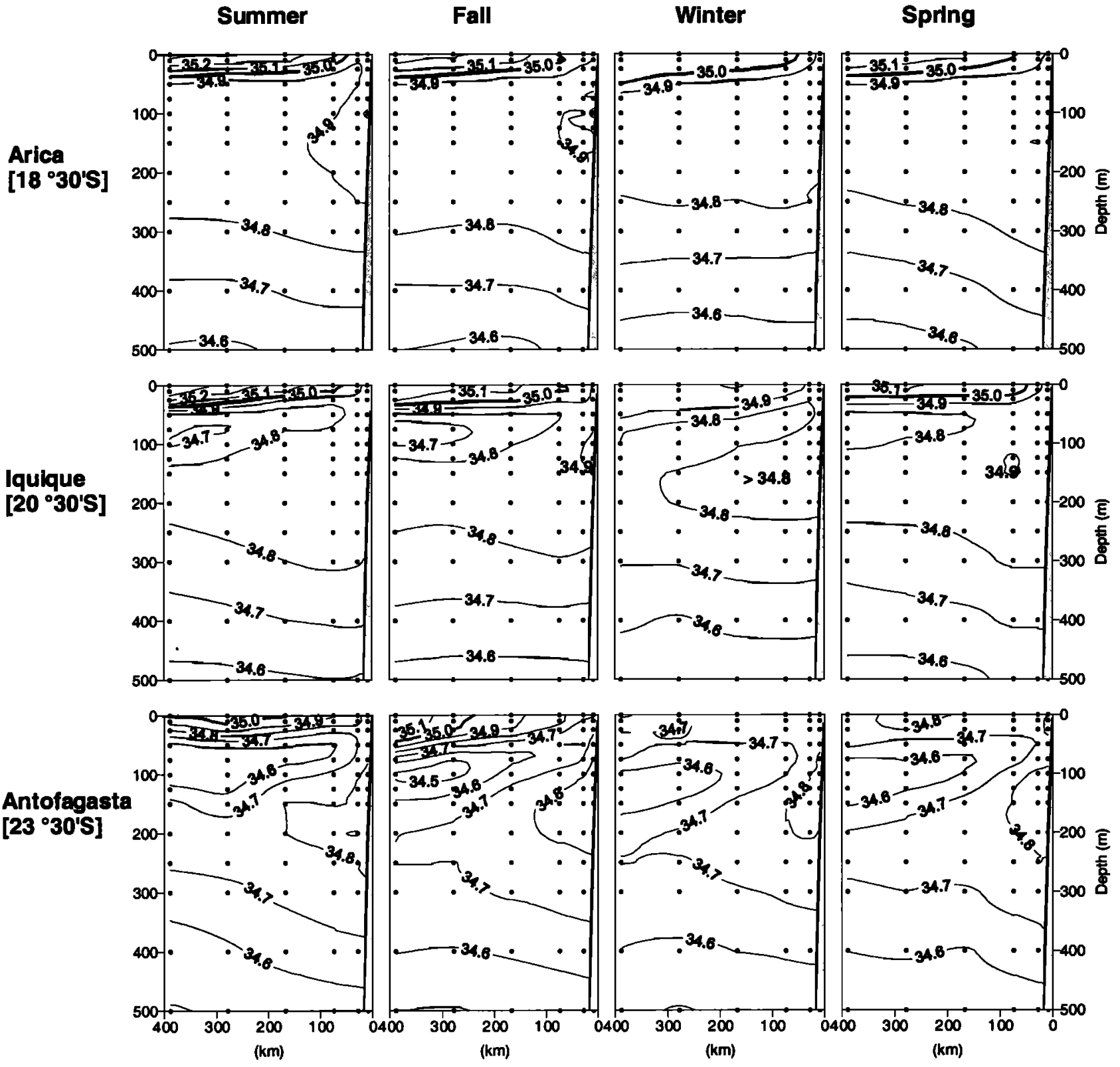

Figure 8. Seasonal climatologies of cross-shelf vertical salinity structure at Arica, Iquique, and Antofagasta.

northern portion of the study area (90-110 $\mathrm{m}$ at Arica) to deepest Many of the features present in the climatology are similar to in the south (150-200 $\mathrm{m}$ at Antofagasta). A distinct oxygen those identified from previous individual surveys off Chile minimum layer is present at middepths, centered at $\sim 250 \mathrm{~m}$, [Brandhorst, 1971; Fonseca, 1989]. The climatology calculated throughout the study area in all seasons. This oxygen minimum here, however, quantifies the mean circulation and water mass is strongest in the northern portion of the study area, with distributions more thoroughly than any previous analysis, concentrations $<0.25 \mathrm{~mL} \mathrm{~L}^{-1}$ at Arica and Iquique, and presenting real means of the data rather than conceptual concentrations $<0.5 \mathrm{~mL} \mathrm{~L}^{-1}$ dominating the water column from schematics. It also differs from climatologies that might be 100 to $450 \mathrm{~m}$. The low oxygen water is associated with ESSW. constructed from global data sets. Figure 10 contrasts the Patterns of low oxygen concentration are consistent with the seasonal climatologies of surface temperature and salinity from hypothesis that ESSW is more dominant in the north and Figure 5 with contours derived from the global data sets of occupies more of the water column in summer than in winter.

\section{Discussion}

Levitus and Boyer [1994]. In the offshore region, the global climatology captures the meridional gradients, although even these are underestimated. Within $200 \mathrm{~km}$ of the coast the relatively course grid scales of the global climatology cannot

The large-scale climatological features quantified here off resolve the zonal gradients associated with upwelling, northern Chile have direct analogues in other eastern boundary eliminating their applicability to studies of processes, events, and current systems which exhibit nearshore upwelling, equatorward anomalies near shore. In a first application, Blanco et al., surface flow, and a poleward undercurrent next to the slope. (submitted manuscript, 2000) use the climatological fields 


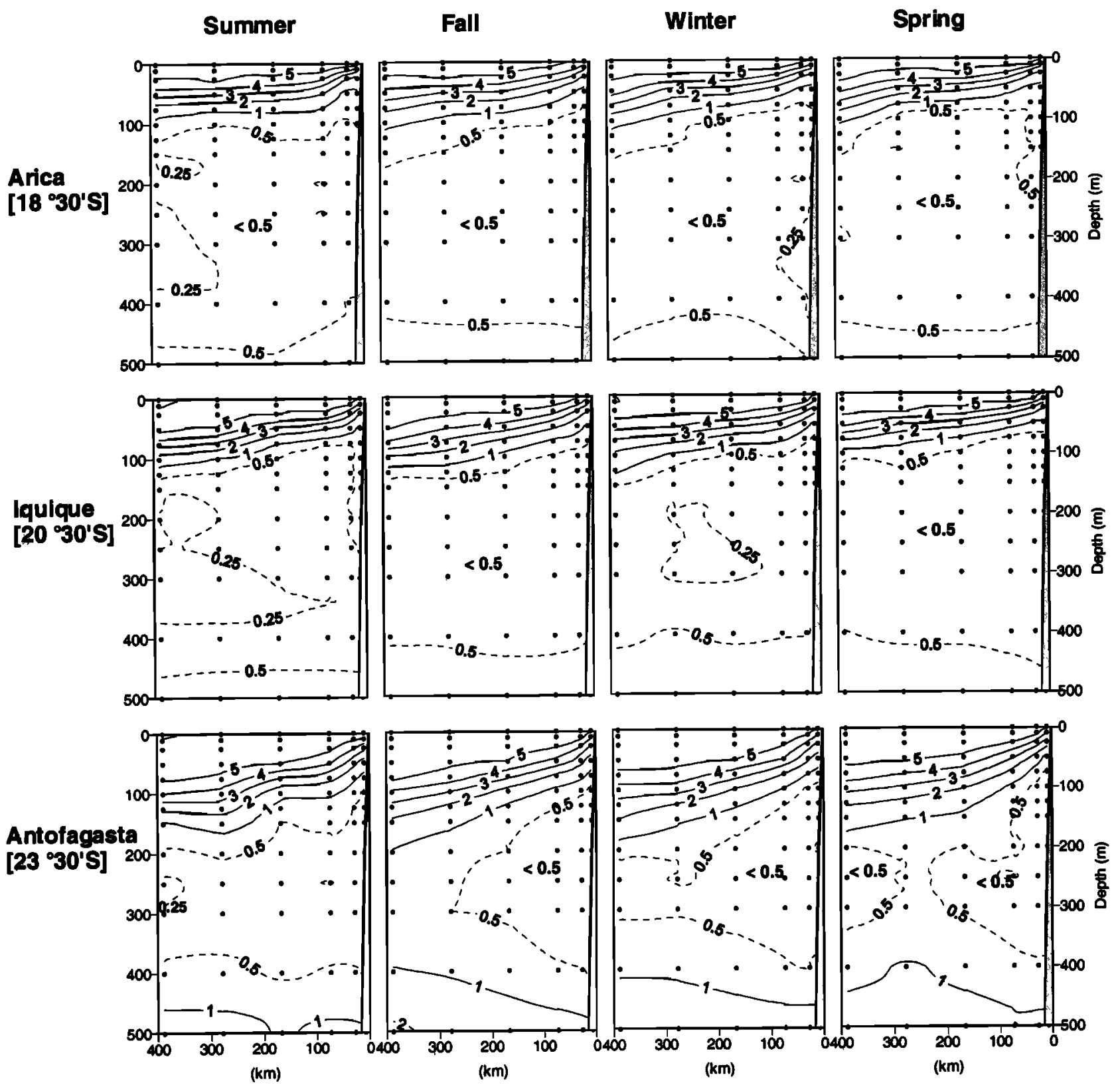

Figure 9. Seasonal climatologies of cross-shelf vertical oxygen structure $\left(\mathrm{mL} \mathrm{L}^{-1}\right)$ at Arica, Iquique, and Antofagasta.

calculated here to form anomalies quantifying 1997-1998 El Niño conditions off northern Chile.

The northern Chilean portion of the Peru-Chile Current system may have specific similarities to low-latitude portions of its Northern Hemisphere analogue, the California Current. Although located at higher latitudes than our study region, winds off Baja California $\left(23^{\circ} \mathrm{N}-32^{\circ} \mathrm{N}\right)$ also remain upwellingfavorable year-round. Direct comparisons to identical latitudes in the Northern Hemisphere are difficult because of the lack of a high resolution climatology off mainland Mexico and, more importantly, strongly dissimilar oceanic current structure and wind forcing caused by the northern displacement of the equatorial current system, its interaction with coastal hydrography, and the seasonality of the Intertropical Convergence Zone. These have no counterpart in our study region. In the southern part of the study region presented here (our closest analogy to Baja California Current latitudes) the maximum in the surface equatorward current shows signs of moving from next to the coast in spring to $150 \mathrm{~km}$ (or farther) from the coast in summer and fall (Figure 6). This is similar to the seasonal offshore migration of the surface equatorward jet in the California Current documented in a number of papers [Chelton, 1984; Lynn and Simpson, 1987; Kosro et al., 1991; Strub et al., 1991; Strub and James, 2000] and evident in the climatological hydrographic data off southern Baja [Lynn et al., 1982]. The poleward undercurrent appears to be stronger in summer off northern Chile. Off the southern part of the California Current (southern California and Baja California) the undercurrent often appears to have a semiannual nature, with maxima in both late summer and winter [Chelton, 1984; Lynn and Simpson, 1987]. The presence of relatively fresh SAW and ESSW at middepth off Chile brings fresher water to the surface 

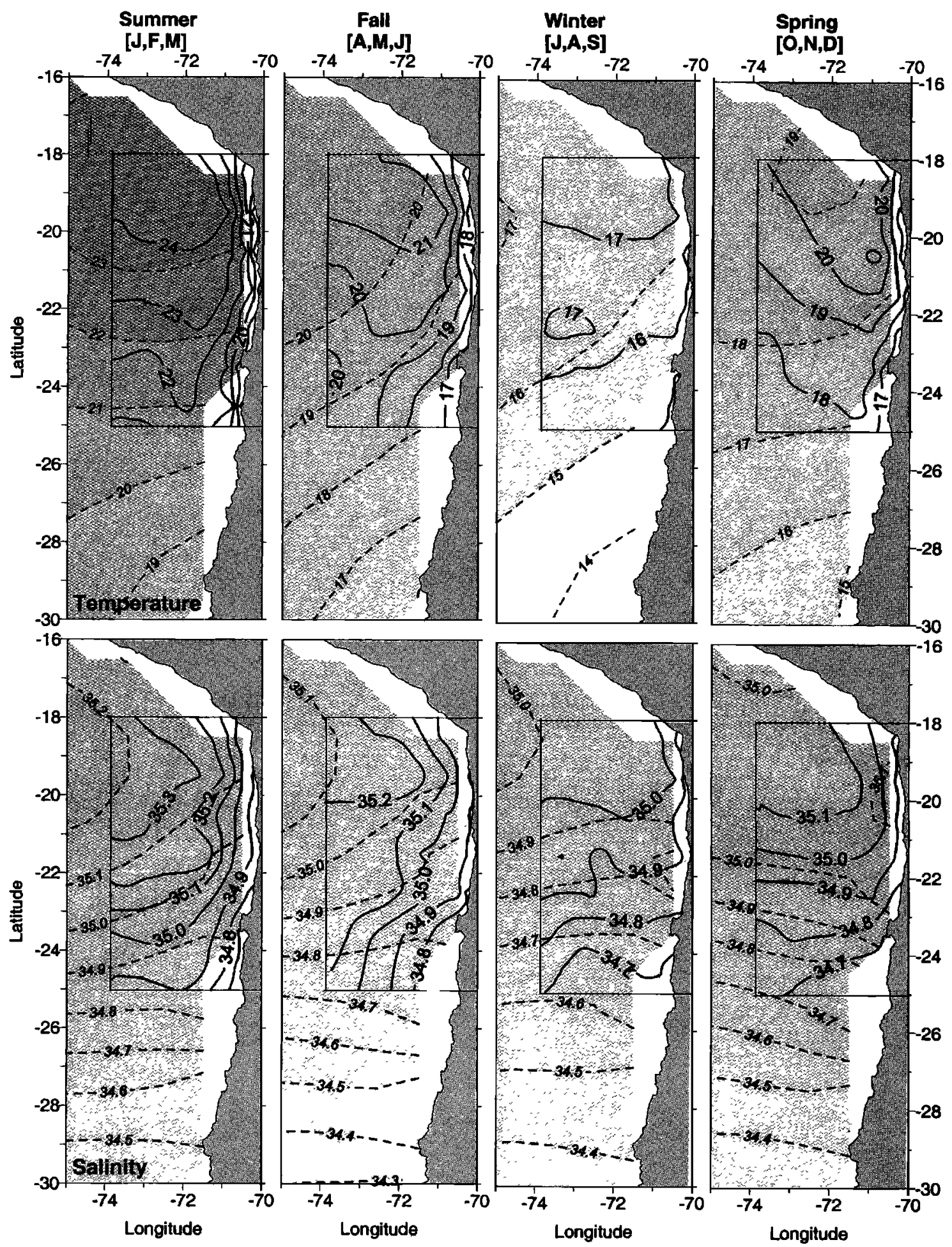

Figure 10. Comparison of the regional climatology calculated here (solid contours) with a global surface seasonal climatology for temperature (top) and salinity (bottom). Dashed contours are those of Levitus and Boyer [1994].

during upwelling. Over much of the California Current the salinity minimum is a surface feature located offshore and relatively saline water is upwelled nearshore. Off southern Baja, however, the salinity minimum is subsurface throughout the year (centered between 100 and $150 \mathrm{~m}$ ). The seasonal maximum in wind forcing during spring and summer (April and July) [Lynn et al., 1982] thus brings relatively fresh water to the surface near the coast. In this characteristic, both regions are similar to the Benguela Current.

One feature that is not seen in the California Current and seems more difficult to explain, is the seasonal cycle of offshore surface salinities (Figure 5). Off northern Chile these are minimum in winter, increasing in spring to a maximum in summer, implying enhanced poleward and onshore movement 
from an equatorial source (STW, Figure 4) during summer. The classical picture of wind-driven upwelling circulation consists of maximum equatorward and offshore surface flow when equatorward winds are strongest (summer). For example, salinities off southern Baja California $\left(25^{\circ} \mathrm{N}\right)$ decrease from $>34.0$ psu in January to 33.7 psu in July [Lynn et al., 1982]. This conceptual model of the currents should move STW farther to the north (equatorward) and offshore, rather than to the south and onshore. Figure 6a indicates weak onshore flow off Arica in spring, but this is strongly zonal. In the offshore region $\left(72^{\circ} \mathrm{W}\right)$, poleward flow is present in summer, but only at lower latitudes, and is directed offshore, not onshore. This offshore poleward flow would bring higher salinity into the region in summer, but only at lower latitudes, presumably as a tongue from the north. Surface salinity patterns in Figure 5, however, imply a broad tongue intruding from the west over much of the northern half of the offshore domain. Subsurface flow (Figure 6b) is predominantly poleward and directed onshore throughout the year, most strongly in spring and summer, but does not account for the summer increase in surface salinity. One explanation of these discrepancies is that deep, large-scale components of flow exist that are not well represented by the geostrophic component relative to $500 \mathrm{~m}$.

In the subsurface water we have referred to offshore low salinities as SAW. We can speculate on the degree to which these low salinities off northern Chile might be influenced by the large freshwater discharge from the fjord region of Chile at latitudes $>42^{\circ} \mathrm{S}$. The situation in this case would be analogous to the freshwater influence of higher latitudes on the California Current. Brandhorst [1971] shows a subsurface tongue of fresh water penetrating north next to the northern Chile and Peru coasts, above the relatively saline undercurrent. In spring and summer, Rojas and Silva [1996] show tongues of fresh water (34.0-34.5 psu) extending north from the higher latitude fjord region at $100 \mathrm{~m}$ depth, sometimes reaching as far north as Antofagasta with salinities of 34.5-34.6 psu, similar to values in the offshore minima presented here (Figure 8). Shaffer et al. [1995] show low-salinity water with a high-latitude origin above $180 \mathrm{~m}$ at $30^{\circ} \mathrm{S}$ in their spring-summer-fall period data. Shaffer et al. [1997, 1999] report mean poleward alongshore velocities of 12 and $12.8 \mathrm{~cm} \mathrm{~s}^{-1}$ at $250 \mathrm{~m}, 10 \mathrm{~km}$ offshore at $30^{\circ} \mathrm{S}$. Alongshore velocity at $250 \mathrm{~m}, 150 \mathrm{~km}$ offshore at $30^{\circ} \mathrm{S}$ [Shaffer et al., 1999] was poleward at $3 \mathrm{~cm} \mathrm{~s}^{-1}$. These patterns are consistent with the poleward geostrophic currents between 200 and $500 \mathrm{~m}$ in the southern portions of our study area (Figure $6 \mathrm{~b})$, suggesting that the general structure of the undercurrent is similar between $30^{\circ} \mathrm{S}$ and the latitudes examined here. Examination of $T-S$ properties (Figure 4) suggests that within the northern Chile region the salinity minima lie along (or slightly above) a line of mixing between ESSW and SAW. Rojas and Silva show fjord water near Chiloe Island $\left(43^{\circ} \mathrm{S}\right)$ with a temperature of $9^{\circ}-10^{\circ} \mathrm{C}$ and salinities of $33.9-34.0$ psu. A hypothetical mixing line between this and ESSW on the $T-S$ plots of Figure 4 would fall below the line connecting ESSW and SAW, farther from the characteristics of the salinity minima found off Antofagasta. Thus we accept the SAW label for our offshore salinity minima, but the data of Brandhorst and that of Rojas and Silva indicate that we cannot rule out the possibility of at least some influence from higher-latitude coastal fjord water extending north into our study area. Further examination of the influence and variability of the freshwater tongue on the northern Chile upwelling region requires analysis of a larger-scale data set than is examined here, allowing connections to be made over larger latitudinal ranges.

The poleward flow evident in offshore regions during summer (and to a lesser extent in spring) in Figure $6 \mathrm{~b}$ may be the signature of the offshore Peru-Chile Countercurrent, the location of which off Chile is subject to controversy. Off Peru, the Countercurrent is seen $\sim 100-300 \mathrm{~km}$ offshore in the data of Huyer et al. [1987]. Indeed, much of the flow off Peru at $10^{\circ} \mathrm{S}$ and $15^{\circ} \mathrm{S}$ is poleward, with only a narrow upper layer of equatorward flow [Brink et al., 1980, 1981; Shaffer, 1982; Huyer et al., 1987]. This predominance of poleward flow may show the influence of the eastward Equatorial Undercurrent, which has been traced into both the poleward undercurrent and the PeruChile Countercurrent off northern Peru [Tsuchiya, 1985; Lukas, 1986]. Off southern Peru and northern Chile, schematic figures drawn by Wyrtki [1966], Bernal et al. [1982], and Fonseca [1989] differ in their depiction of the Countercurrent. The schematic figure drawn by Wyrtki continues the path of the countercurrent straight south from its location off Peru, thus far offshore of the Chilean coast, splitting the equatorward "Peru Current" into offshore and coastal branches. The descriptions of Bemal et al. and Fonseca indicate a poleward flow 100-300 km offshore. The geopotential anomaly fields from the two summer cruises analyzed by Brandhorst [1971] also show poleward flow off northern Chile between $100-200 \mathrm{~km}$ offshore as found here (they did not sample the region where Wyrtki draws the Countercurrent). Strub et al. [1995] use 3 years of altimeter data to show poleward surface currents in a region that follows the Peru and Chile coasts about $100-300 \mathrm{~km}$ offshore, from about $6^{\circ}-35^{\circ} \mathrm{S}$. They show that poleward flow is maximum in spring, when the trade winds decrease over the eastern equatorial Pacific, and minimum (or reversed) in fall, when the trade winds increase. The increase in STW in summer discussed in the previous paragraph is consistent with poleward and onshore flow caused by an offshore countercurrent off northern Chile, integrating the effects of a spring maximum in flow to result in a summer maximum in STW concentrations. A more detailed study of the circulation in this region is needed to describe the existence and behavior of the Peru-Chile Countercurrent with more certainty.

Maps of geopotential anomaly variance for the California Current [Lynn and Simpson, 1987] show a maximum in the region $200 \mathrm{~km}$ offshore off Baja $\left(25^{\circ}-30^{\circ} \mathrm{N}\right)$. Lynn and Simpson call this the "coastal transition zone" and suggest that eddies in this region are responsible for this maximum in variance, although the annual variance they present includes the seasonal cycle and its associated cross-shelf variability. Strub and James [2000] show a similar maximum in seasonal maps of geostrophic velocity variance derived from altimeter data. The variance maximum moves from nearshore in spring to offshore in summer and fall, following the migration of the seasonal jet. They hypothesize that the variance maximum is caused by both meanders in the jet and eddies created on either side of the jet as it moves offshore. Is there an analog off northern Chile? There is indirect evidence for eddy activity within the upwelling front from satellite data. Fonseca and Farias [1987], Yáñez et al. [1995], and Barbieri et al. [1995] show examples of satellite SST images from northern Chile which depict filaments in the mesoscale SST structure. These appear to have offshore length scales of $60-125 \mathrm{~km}$. Surface color images from northern Chile also include filaments on the order of $100-200 \mathrm{~km}$ offshore [Thomas, 1999]. Using the hydrographic data for the northern 


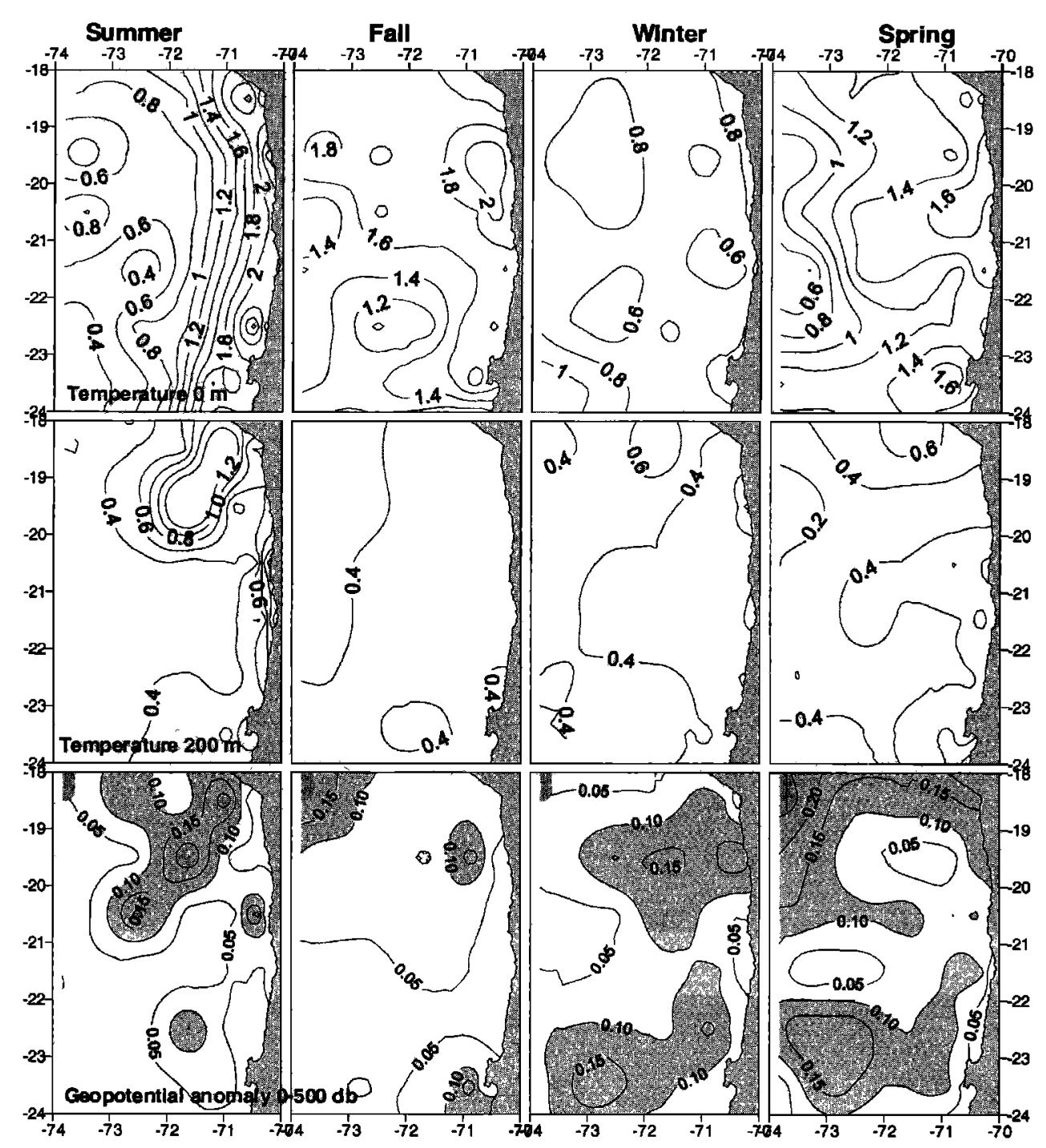

Figure 11. Spatial patterns of variance for each season of (a) surface temperature, (b) temperature at $200 \mathrm{~m}$, and (c) geopotential anomaly (0 to $500 \mathrm{dbar})$.

Chile region, Figure 11 presents the seasonal distributions of the standard deviations of surface temperature, temperature at $200 \mathrm{~m}$ and geopotential anomaly (surface relative to $500 \mathrm{dbar}$ ). The standard deviation in each field is calculated from the individual temperature and salinity profiles within a season, and the seasonal mean is subtracted to form the variances. These standard deviations thus represent variability within each season and between years (not the variance caused by mean seasonal changes). Spring and summer standard deviations in SST are highest next to the coast, clearly reflecting temporal variations in coastal upwelling. This is also true in summer for temperature at $200 \mathrm{~m}$ south of $20^{\circ} \mathrm{S}$. North of $20^{\circ} \mathrm{S}$, the dominant feature in the $200 \mathrm{~m}$ temperature variance field is associated with the anticyclonic gyre identified in Figure 6b. The pattern of standard deviation in surface geopotential is less spatially coherent than that of temperature. It exhibits offshore maxima off Antofagasta $\left(22^{\circ}-24^{\circ} \mathrm{S}, 100-250 \mathrm{~km}\right.$ offshore $)$ in winter and spring and off Arica (north of $20^{\circ} \mathrm{S}$ ) in spring and fall. These geopotential variance patterns, predominantly aligned zonally, are clearly different from the meridionally aligned contours off SST standard deviation, associated with upwelling. These maxima may indicate greater eddy variability, but elevated error due to reduced sampling in the offshore grid locations and lack of a clear seasonal progression prohibits further interpretation. In the north the one signal which is consistent with previously identified fields is the variance associated with the anticyclonic circulation in summer between $18^{\circ} \mathrm{S}$ and $21^{\circ} \mathrm{S}, 100-300 \mathrm{~km}$ offshore.

To what extent do we expect the climatology calculated here to represent patterns at higher latitudes off Chile? Offshore, meridional gradients suggest that the influence of AIW and SAW should increase as one moves toward higher latitudes, while ESSW should become less prevalent. Brandhorst [1971] traced the poleward undercurrent next to the coast during summer as far south as his data allowed $\left(\sim 42^{\circ} \mathrm{S}\right)$ and Silva and Neshyba [1979] find it as far south as $48^{\circ} \mathrm{S}$. The offshore poleward countercurrent is said to occur as far south as $33^{\circ} \mathrm{S}$ [Fonseca, 1989; Bernal et al., 1982]. It appears even farther to the south in the 3 years of altimeter data presented by Strub et al. [1995]; however, a more systematic examination of a longer time series of in situ and satellite data is needed to establish the true nature of the Peru-Chile Countercurrent off central Chile. The data here 
only hint at its existence off northern Chile. With regard to the equatorward surface flow, wind forcing during winter becomes increasingly poleward (downwelling favorable) at higher latitudes [Bakun and Nelson, 1991; Thomas, 1999], making upwelling and surface equatorward flow increasingly seasonal. Bathymetry also changes at higher latitudes; the extremely narrow shelf off northern Chile widens to $30-50 \mathrm{~km}$ south of $30^{\circ}-33^{\circ} \mathrm{S}$, the latitude at which distinct changes cross-shelf phytoplankton seasonality occur [Thomas, 1999]. Thus, although the circulation depicted here in the southern half of the study region may represent the circulation to some distance south of $24^{\circ} \mathrm{S}$, the seasonality and basic nature of the surface and nearshore flow are likely to change south of $\sim 30^{\circ} \mathrm{S}$.

\section{Summary}

Climatological hydrography in the upwelling region off northern Chile is presented for the first time at sufficient crossshelf resolution to resolve features of coastal upwelling. Quantified fields are thus amenable to comparison both with similar calculations in other eastern boundary current regimes and also with mesoscale surveys within the study area, facilitating examinations of interannual variability. The climatological seasonal alongshore wind forcing is equatorward (upwelling favorable) at all times and locations but weaker in the far north, where the amplitude of the seasonal cycle is also weakest. Maximum equatorward winds occur in spring and summer, with a greater annual range of wind speed in the center of the study region. Coastal water temperatures and sea levels are greater in summer than winter, reflecting the seasonal cycle of heating and expansion. Annual minimum coastal temperatures and sea levels lag those of wind, most likely reflecting the influence of increased upwelling in spring.

Surface climatological water mass characteristics offshore are those of STW (warm, salty). Between 50 and $300 \mathrm{~m}$ the offshore region is characterized by a SAW influence (fresh), while next to the coast in the poleward undercurrent, characteristics are those of ESSW (salty). The surface water next to the coast is a mix of upwelled ESSW and SAW. Below $400 \mathrm{~m}$, salinities decrease as water characteristics move toward AIW. There are north-south gradients in these properties, with a greater presence of STW and ESSW in the north and a greater presence of SAW in the south, consistent with the source locations and the direction of flow. In the offshore half of the study region, there appears to be an onshore movement of STW at the surface and of SAW at middepth during the summer and fall.

Surface hydrographic fields indicate year-round coastal upwelling of colder, less saline water, strongest in summer and weakest in winter. Offshore, surface climatological patterns are oriented zonally, reflecting the seasonal cycle of solar heating. Geostrophic circulation is stronger and more consistent in the southern half of the study area $\left(21^{\circ}-24^{\circ} \mathrm{S}\right)$ than in the northern half $\left(18^{\circ}-21^{\circ} \mathrm{S}\right)$. In the southern half, surface flow is equatorward during all seasons and subsurface flow $(200 \mathrm{~m})$ is poleward in the region within $200 \mathrm{~km}$ of the coast, but very weak in winter. There is also a tendency for onshore-directed flow at $200 \mathrm{~m}$. In the northern part of the study area, surface flow is weak and onshore in spring, then more equatorward in summer, fall, and winter. In summer a closed anticyclonic gyre extending below $200 \mathrm{~m}$ appears in the northern region. Subsurface flow in the northem part of the study area is poleward in spring and summer but weak and mostly onshore in fall and winter.
Acknowledgments. The extensive hydrographic data presented here, collected over 32 years, are possible only because of the dedicated efforts of a large number of people at multiple institutions. These data and support for J.L.B. were provided by IFOP, with funding by Fondo de Investigacion Pesquera (projects 95-05, 96-07, and 97-07). Wind data came from the Direccion Meteorologica de Chile, and temperature data at coastal tide gauges came from SHOA. Monthly sea levels at the tide gauges were obtained from the University of Hawaii. Funding for A.C.T. came from NASA grants NAG5-6558 and NAG5-6604 and NSF grant OCE-9711919 (part of the U.S. GLOBEC program). Funding for M.E.C. was provided by the NASA Ocean Biogeochemistry Program and for P.T.S. by JPL grant 958128 (TOPEX) and NASA grants NAG5-4947 (EOS) and NAG5-6604. Additional funding for travel for all authors to collaborate in the analysis of these data came from an NSF supplement to grant OC-9711344 (part of the U.S. GLOBEC program). This is contribution number 178 from the U.S. GLOBEC program.

\section{References}

Bakun, A., and C.S. Nelson, The seasonal cycle of wind stress curl in sub-tropical eastern boundary current regions, J. Phys. Oceanogr., 21, 1815-1834, 1991.

Barbieri, M.A., M. Bravo, M. Farías, A. Gonzalez, O. Pizarro, and E. Yáñez, Fenómenos asociados a la estructura térmica superficial del mar observados a través de imágenes satelitales en la zona norte de Chile. Invest. Mar., 23, 99-122, 1995.

Bernal, P.A., F.L. Robles, and O. Rojas, Variabilidad fisica y biologica en la región meridional del sistema de corrientes Chile-Perú. Monogr. Biol., 2, 75-102, 1982.

Blanco, J. L., Variabilidad termica y salina en la zona norte de Chile, Inf. interno para IFOP, Inst. de Fomento Pesquero, Valparaíso, Chile, 1996.

Brandhorst, W., Condiciones oceanograficas estivales frente a la costa de Chile. Rev. Biol. Mar., 14(3), 45-84, 1971.

Brasseur, P., J.M. Beckers, J.M. Brankart, and R. Schoenauen, Seasonal temperature and salinity fields in the Mediterranean Sea: Climatological analyses of an historical data set, Deep Sea Res., Part I, 43(2), 159-192, 1996.

Brink, K.H., D. Halpern, and R.L. Smith, Circulation in the Peruvian upwelling system near $15^{\circ} \mathrm{S}, J$. Geophys. Res., 85, 4036-4048, 1980.

Brink, K.H., B.H. Jones, J.C. Van Leer, C.N.K. Mooers, D.W. Stuart, M.R. Stevenson, R.C. Dugdale, and G.W. Heburn, Physical and biological structure and variability in an upwelling center off Peru near $15^{\circ} \mathrm{S}$, during March 1977 , in Coastal Upwelling, Coastal Estuarine Sci., vol. 1, edited by F.A. Richards, pp. 473-495, AGU, Washington, D. C., 1981.

Carpenter, J.H., The Chesapeake Bay Institute Technique for the Winkler dissolved oxygen method, Limnol. Oceangr., 10, 141-143, 1965.

Carr, M.-E., E. J. Kearns, and H. T. Rossby, Isopycnal RAFOS floats as roving hydrographers in the North Atlantic Current region, Geophys. Res. Lett., 24 (5), 551-554, 1997.

Chelton, D.B., Seasonal variability of along-shelf geostrophic velocity off central California, J. Phys. Oceanogr., 12, 757-784, 1984.

Chelton, D.B., P.A. Bernal, and J.A. McGowan, Large-scale interannual physical and biological interaction in the California Current, J. Mar. Res., 40, 1095-1125, 1982.

Fonseca, T.R., An overview of the poleward undercurrent and upwelling along the Chilean coast, in Poleward Flows Along Eastern Ocean Boundaries, edited by S. J. Neshyba et al., pp. 203-228, SpringerVerlag, New York, 1989.

Fonseca,T.R., and M. Farías, Estudio del proceso de surgencia en la costa chilena utilizando percepción remota, Invest. Pesq., 34, 33-46, 1987.

Fuenzalida, R., Variabilidad temporal de un indice de surgencia para la zona de Iquique (Lat. 20S), Invest. Cient. y Tec., Cienc. Mar., I, 37-47, 1989.

Gunther, E. R., A report on oceanographical investigation in Peru Coastal Current, Discov. Rep., 13, 107-276, 1936.

Huyer, A., R.L. Smith, and T. Paluszkiewicz, Coastal upwelling off Peru during normal and El Niño times, 1981-1984, J. Geophys. Res., 92, 14,297-14,307, 1987.

IFOP, Evaluacion conjunta de los stocks de sardina y anchoveta del sur del Peru y norte de Chile, Inst. de Fomento Pesquero de Chile - Inst. del Mar Peru, Inf. final del grupo de trabajo sobre pesquerias pelagicos, 50 pp., Valparaíso, Chile, 1998. 
IFOP, Investigación de la situacion de las principales pesquerias pelagicas, zona norte 1998, Informe final de proyecto, 50 pp., Inst. de Fomento Pesquero, Valparaíso, Chile, 1999.

Inostroza, J., Atlas Oceanogr fico de Chile. IHA Publ. 304I, Inst. Hidro. de la Armada de Chile, 1972.

Kearns, E. J., and H. T. Rossby, Historical position of the North Atlantic Current, J. Geophys. Res., 103, 15,509-15,524, 1998.

Kosro, P.M., et al., The structure of the transition zone between coastal waters and the open ocean off northern California, winter and spring 1987, J. Geophys. Res., 96, 14,707-14,730, 1991.

Levitus, S., and T.P. Boyer, World Ocean Atlas 1994, vol. 4, Temperature, NOAA Atlas NESDIS 4, 117 pp., U.S. Gov. Print. Off., Washington, D. C., 1994.

Lozier, M.S., W.B. Owens, and R.G. Curry, The climatology of the North Atlantic, Prog. Oceanogr., 36, 1-44, 1995.

Lukas, R., The termination of the Equatorial Undercurrent in the eastern Pacific, Prog. Oceanogr., 16, 63-90, 1986.

Lynn, R.J., and J.J. Simpson, The California Current System: The seasonal variability of its physical characteristics, J. Geophys. Res., 92, 12,947-12,966, 1987.

Lynn, R.J., K.A. Bliss, and L.E. Eber, Vertical and horizontal distributions of seasonal mean temperature, salinity, signa-t, stability, dynamic height, oxygen, and oxygen saturation in the California Current, 1950-1978, Calif. Coop. Oceanic Fish. Invest., Atlas 30, 513 pp., 1982.

Pizarro, O., S. Hormazabal, A. González, and E. Yáñez, Variabilidad del viento, el nivel del mar y la temperatura en la costa norte de Chile, Invest Mar. , 22, 85-101, 1994.

Roemich, D., and J. McGowan, Climatic warming and the decline of zooplankton in the California Current, Science, 267, 1324-1326, 1995.

Rojas, R., and N. Silva, Atlas Oceanográfico de Chile, Vol. 1 [18 $21^{\circ}$ 'S a $50^{\circ} 00^{\prime}$ S], Serv. Hidro. y Oceanogr. de la Armada de Chile, Valparaíso, Chile, 1996.

Rowley, C., and L. M. Rothstein, On the interaction of the North Atlantic Current with the bathymetry of the Newfoundland Basin, Eos Trans., AGU, 79(45), Fall Meet. Suppl., 457, 1998.

Shaffer, G., On the upwelling over the wide shelf off Peru, 1 , Circulation, J. Mar. Res., 40, 292-314, 1982.

Shaffer, G., S. Salinas, O. Pizarro, A. Vega, and S. Hormazabal, Currents in the deep ocean off Chile ( $\left.30^{\circ} \mathrm{S}\right)$, Deep Sea Res., Part $I$, $26,1387-1393,1995$.

Shaffer, G., O. Pizarro, L. Djurfeldt, S. Salinas, and J. Rutllant, Circulation and low-frequency variability near the Chilean coast: Remotely forced fluctuations during the 1991-1992 El Niño, J. Phys. Oceanogr., 27, 217-235, 1997.

Shaffer, G., S. Hormazabal, O. Pizarro, and S. Salinas, Seasonal and interannual variability of currents and temperature off central Chile, J. Geophys. Res., 104, 29,951-29,961, 1999.

Silva, N., and T.R. Fonseca, Geostrophic component of the oceanic flow off northern Chile. Conferencia Internacional Sobre Recursos
Marinos del Pacifico, edited by P. Arana, pp. 59-70, Vina del Mar, 1983.

Silva, N., and S. Neshyba, On the southernmost extension of the PeruChile Undercurrent, Deep Sea Res., Part A, 26, 1387-1393, 1979.

Strub, P.T., and C. James, Altimeter-derived variability of surface velocities in the California Current System: 2. Seasonal circulation and eddy statistics, Deep Sea Res. Part II, 47, 831-870, 2000.

Strub, P.T., J.S. Allen, A. Huyer, R.L. Smith, and R.C. Beardsley, Seasonal cycles of currents, temperatures, winds and sea level over the northeast Pacific continental shelf: $35^{\circ} \mathrm{N}$ to $48^{\circ} \mathrm{N}, J$. Geophys. Res., 92, 1507-1526, 1987.

Strub, P.T., P.M. Kosro, A. Huyer, and CTZ Collaborators, The nature of the cold filaments in the California Current System, J. Geophys. Res., 96, 14,743-14,768, 1991.

Strub, P.T., J.M. Mesias, and C. James, Altimeter observations of the Peru-Chile Countercurrent, Geophys. Res. Lett., 22, 211-214, 1995.

Strub, P.T., J.M. Mesias, V. Montecino, J. Rutllant, and S. Salinas, Coastal ocean circulation off western South America, in The Sea, Vol. 11, edited by A.R. Robinson and K.H. Brink, pp. 273-313, John Wiley, New York, 1998.

Thomas, A.C., Seasonal distributions of satellite-measured phytoplankton pigment concentration along the Chilean coast, $J$. Geophys. Res., 104, 25,877-25,890, 1999.

Thomas, A.C., J.L. Blanco, M. -E. Carr, P. T. Strub, and J. Osses, Satellite-measured chlorophyll and temperature variability off northern Chile during the 1996-1998 La Niña and El Niño, $J$. Geophys. Res., 106, 901-917, 2001.

Tsuchiya, M., The subthermocline phosphate distribution and circulation in the far eastern Equatorial Pacific Ocean. Deep Sea Res., Part I, 32, 299-313, 1985

Wyrtki, K., Oceanography of the eastern Equatorial Pacific Ocean, Oceanogr. Mar. Biol., 4, 33-68, 1966.

Yánez, E., A. Gonzalez, and M.A. Barbieri, Sea surface thermal structure associated to the space-temporal distribution of sardine and anchovy in northern Chile, Invest. Mar., 23, 123-147, 1995.

J.L. Blanco, Department of Ocean, Earth and Atmospheric Sciences, old Dominion University, Norfolk, VA, 23529.

(jlblanco@ccpo.odu.edu)

M.-E. Carr, Jet Propulsion Laboratory, California Institute of Technology, MS 300-323, 4800 Oak Grove Dr., Pasadena, CA 91009 8099. (mec@pacific.jpl.nasa.gov)

P.T. Strub, College of Oceanic and Atmospheric Sciences, Oregon State University, Corvallis, OR 97331-5503. (tstrub@oce.orst.edu)

A.C. Thomas, School of Marine Sciences, University of Maine, Orono, ME 04469-5741. (thomas@maine.edu)

(Received July 11, 2000; revised January 15, 2001 accepted February 26, 2001.) 